University of Nebraska - Lincoln

DigitalCommons@University of Nebraska - Lincoln

Educational Investment, Family Context, and Children's Math and Reading Growth from Kindergarten through the Third Grade

Jacob Cheadle

University of Nebraska-Lincoln, jcheadle2@unl.edu

Follow this and additional works at: https://digitalcommons.unl.edu/sociologyfacpub

Part of the Sociology Commons

Cheadle, Jacob, "Educational Investment, Family Context, and Children's Math and Reading Growth from Kindergarten through the Third Grade" (2008). Sociology Department, Faculty Publications. 116.

https://digitalcommons.unl.edu/sociologyfacpub/116

This Article is brought to you for free and open access by the Sociology, Department of at DigitalCommons@University of Nebraska - Lincoln. It has been accepted for inclusion in Sociology Department, Faculty Publications by an authorized administrator of DigitalCommons@University of Nebraska - Lincoln. 


\title{
Educational Investment, Family Context, and Children's Math and Reading Growth from Kindergarten through the Third Grade
}

\author{
Jacob E. Cheadle \\ University of Nebraska-Lincoln
}

\begin{abstract}
Drawing on longitudinal data from the Early Childhood Longitudinal Study, Kindergarten Class of 19981999, this study used IRT modeling to operationalize a measure of parental educational investments based on Lareau's notion of concerted cultivation. It used multilevel piecewise growth models regressing children's math and reading achievement from entry into kindergarten through the third grade on concerted cultivation and family context variables. The results indicate that educational investments are an important mediator of socioeconomic and racial/ethnic disparities, completely explaining the black-white reading gap at kindergarten entry and consistently explaining 20 percent to 60 percent and 30 percent to 50 percent of the black-white and Hispanic-white disparities in the growth parameters, respectively, and approximately 20 percent of the socioeconomic gradients. Notably, concerted cultivation played a more significant role in explaining racial/ethnic gaps in achievement than expected from Lareau's discussion, which suggests that after socioeconomic background is controlled, concerted cultivation should not be implicated in racial/ethnic disparities in learning.
\end{abstract}

The finding that children of different racial groups and socioeconomic backgrounds begin their formal educational careers with disparities in skills on standardized tests (e.g., Lee and Burkam 2002) and that these inequalities persist through primary and secondary school (Phillips, Crouse, and Ralph 1998) is well established. Although parenting practices play an important role in the development of differences in early childhood achievement (Guo 1998; J. R. Smith, Brooks-Gunn, and Klebanov 1997), less is known about the role that families play in disparities in achievement once children enter elementary school. In her ethnographic study, Lareau $(2002,2003)$ reported pronounced social-class differences in the ways parents organize their children's lives around adult-orchestrated lei- sure activities, interact with teachers and the educational system, and verbally and academically engage their children. According to Lareau (2003), different ways of organizing their children and their own lives along these dimensions reflect contrasting parental investments in children's educational growth, which ultimately has important consequences for the skills and abilities that children develop.

Lareau's research is part of an older tradition that has noted meaningful variation in class-based parenting strategies (e.g., Kohn 1977) and provides an important avenue for the operationalization of parents' patterns of educational investment. Indeed, although Lareau (1989) was critical of the often narrow foci of quantitative research, her most 
recent work (Lareau 2002, 2003) applies well to the quantitative study of numerous dimensions of children's lives. By mapping out broad patterns of parental investment and the implications of these patterns for children, Lareau's (2003) detailed ethnographic account articulates a number of hypotheses about patterns of parental educational investments and outcomes, such as children's educational achievement. Notably, however, Lareau (2003) suggested that there are few black-white differences in the endorsement of contemporary parenting practices, which suggests that the socioeconomic and social class-based patterns of investment that she described are not useful for understanding the gaps in black-white test scores.

In this article, I use the Early Childhood Longitudinal Study, Kindergarten Class of 1998-99 (ECLS$\mathrm{K})$, to assess the role of what Lareau termed "concerted cultivation" on children's math and reading achievement from kindergarten entry through the spring of third grade. Lareau's (2003) research suggests that a composite measure of parenting that is based on three dimensions of educational investment (1) should be related to children's skill levels at kindergarten entry and to (2) children's educational development after they enter school, (3) should play a significant role in explaining socialclass or socioeconomic gaps in children's learning, and (4) should not be significantly associated with racial/ethnic differences in children's learning after socioeconomic or social-class background are adjusted for.

\section{Literature Review}

\section{Academic Achievement}

Although not all studies have found substantial differences in children's early academic competencies (see Entwisle, Alexander, and Olson 1997), many studies have reported pronounced early learning differences by race and socioeconomic background (Applebee, Langer, and Mullis 1988; Farkas and Beron 2004; Hart and Risley 1995; Lee and Burkam 2002; Phillips, Brooks-Gunn et al. 1998; Stipek and Ryan 1997). Furthermore, there is evidence that racial and socioeconomic disparities grow over time (Alexander, Entwisle, and Olson 2001; Boardman et al. 2002; Bryk and Raudenbush 1988; Downey, von Hippel, and Broh 2004; Farkas and Beron 2004; Fryer and Levitt 2004; Phillips, Crouse, and Ralph 1998; Reardon 2003) and that much of the growth in disparities is attributable to nonschool factors or factors that vary within schools (Downey et al. 2004; Reardon 2003). Lareau (2003) reported that parents of different social classes have different perceptions of their roles in facilitating their children's development of cognitive and noncognitive skills. These different perceptions, she argued, lead parents to endorse disparate patterns of educational investment that result in a stratification of life experiences, producing educational inequalities and playing a key role in the reproduction of social class.

\section{Concerted Cultivation}

Lareau (2003) offered a series of pathways through which social class is reproduced intergenerationally. Arguing that these pathways cluster into coherent patterns of family life, largely defined by differences in the organization of children's daily lives, disparate patterns of language use and academic engagement, and the ways that parents interact with other institutions like schools, she suggested that specific constellations of these three dimensions of parenting practices constitute a relatively homogeneous dichotomization of parental investments in children's education and socialization.

Mapping this dichotomous typology of broad approaches to child rearing onto parental socialclass background, Lareau (2003) suggested that higher-class parents engage in "concerted cultivation" - the deliberate cultivation of cognitive and social skills, whereas lower-class parents engage in a collection of practices that she termed "the accomplishment of natural growth," which are geared toward children's spontaneous, rather than guided, development. These patterns of parental educational investments capture important elements of human (Becker 1964), social (Coleman 1988), and cultural capital (Bourdieu 1977a, 1977b, 1984, 1986; 
Bourdieu and Passeron 1977), preparing children for life as members of the social class or socioeconomic strata into which they are born.

The typology of concerted cultivation and accomplishment of natural growth is based on a three-dimensional classification of parental investments. First, Lareau (2003) found, parents of different social classes expended different levels of interest and energy in children's activities outside school, with advantaged children leading highly structured lives defined by high levels of participation in formalized, adult-guided play (e.g., soccer, music lessons). Second, they also interacted differently with professionals like educators and physicians, with higher-class parents more comfortable and, consequently, more likely to seek out interactions with professionals for their children's benefit. It is not surprising that the advantaged concerted-cultivating parents were more comfortable with their children's teachers and more involved with their children's schools and details of schooling than were the lower-class parents (see also Lareau 1989). Third, the parents spoke differently to their children, with the lower-class parents much more likely to use directives and restricted codes of speech and the advantaged parents more likely to reason and negotiate with their children. The concerted-cultivating parents not only used more cognitively demanding modes of speech, but expended greater efforts in seeking out appropriate educational materials to encourage their children's learning by fostering old and creating new educational interests.

Lareau's (2003) observations are globally consistent with previous quantitative research that demonstrated that advantaged children are involved in more extracurricular activities (e.g., Dumais 2002), that their parents are more involved with their school (Sui-Chu and Willms 1996), and that socioeconomic indictors like family income and maternal education operate through the home environment (Brooks-Gunn, Klebanov, and Duncan 1996; Guo and Harris 2000; Mayer 1997; J. R. Smith et al. 1997). Furthermore, indicators of socioeconomic status (SES) have been associated with parenting styles that have indirect effects on achievement through home skill-building activ- ities and school behaviors (DeGarmo, Forgatch, and Martinez 1999). In addition, higher-SES parents engage children in more conversations, read to their children more, and provide more teaching experiences (e.g., Bradley et al. 2001). Their conversations are richer, contain more contingent responsiveness, and include more efforts to elicit children's speech, and their teaching styles include more scaffolding and complex verbal strategies (Bradley and Corwyn 2002; Hart and Risley 1995; Heath 1983; Sénéchal and LeFevre 2002; K. E. Smith, Landry, and Swank 2000).

\section{Socioeconomic Background, Race, and Concerted Cultivation}

Although Lareau's observations are globally consistent with the large literature on parenting, there are important elements of potential ill fit or mischaracterization. These elements include (1) whether black (and other nonwhite) parents engage in similar levels of concerted cultivation after economic resources and socioeconomic background are accounted for, (2) whether the extent to which social-class or socioeconomic differences in the endorsement of concerted cultivation are due to different conceptualizations of childhood reflecting contemporary class culture or to restricted economic resources, and (3) the extent to which concerted cultivation is categorically distributed or is distributed more heterogeneously and can be modeled as a continuous function of observed behaviors.

Lareau's suggestion that black-white differences in the endorsement of concerted cultivation, net of socioeconomic or social-class background, is a contentious finding. In another ethnographic study, Pattillo-McCoy (1999) documented the myriad ways that segregation and residential housing patterns affect the lives of middle-class blacks. She found that because many middle-class black families live in close proximity to the poor, the demands on the parents are different from those of white middle-class parents, since these parents must help their children navigate different sociospacial and cultural contexts. Thus, while many middle-class black parents must help their children navigate be- 
ing black in largely white environments, as Lareau (2003) discussed, many black families and children must also navigate being middle class in less-advantaged black environments, which may result in different strategies and patterns of parental investment. At least one operationalization of concerted cultivation using a nationally representative survey found that even after a variety of background characteristics, including socioeconomic background, are controlled, black, Hispanic, and Asian parents are far less likely to endorse concerted cultivation than are white parents, which stands in sharp contrast to expectations derived from Lareau's (2003) discussion and suggests that in addition to socioeconomic background or social class, the practice of concerted cultivation may be implicated in racial/ ethnic gaps in learning (Cheadle 2005; Cheadle and Amato 2007).

Chin and Phillips (2004) suggested that parents of different socioeconomic backgrounds endorse similar underlying parenting strategies and that the observed social-class gaps in educational investments that Lareau described result from lower levels of resources, rather than from socioeconomically graded conceptions of how childhood should be constructed. Furthermore, their results indicated that parental investments follow a more gradational and heterogeneous distribution than Lareau's (2003) dichotomous typology proposed and that the categorical distribution of investments that Lareau described may be an artifact of her small sample and sampling procedures. In addition, in attempting to operationalize a measure of concerted cultivation, quantitative researchers have found that a continuous measure performed well (Cheadle 2005; Cheadle and Amato 2007).

\section{Research Questions}

This study adds to recent contributions using the ECLS-K that have modeled changes in children's reading and math scores from kindergarten through the first grade (Downey et al. 2004; Reardon 2003). However, it went beyond these initial descriptive studies by including an additional wave of third-grade data and elaborating the between- child components of the model with indicators of the family context, with particular attention to parents' educational investments, operationalized as closely as possible to Lareau's (2003) discussion. Conditional on the adequate operationalization of concerted cultivation (discussed later), Lareau's research suggests a number of hypotheses. Parental investment, operationalized as concerted cultivation, should (1) be related to children's academic skills at kindergarten entry and growth in achievement after school entry, (2) play a significant role in explaining social-class or socioeconomic gaps in children's learning, and (4) not be significantly associated with racial/ethnic differences in children's learning after socioeconomic or social-class background is adjusted for. However, other scholars have suggested contrasting hypotheses. Chin and Phillips's (2004) findings indicate that to the extent to which different levels of parental educational investments result from resources, rather than social components, concerted cultivation should mediate the economic and occupational components of socioeconomic background, whereas Cheadle and Amato's (2007) results suggest that concerted cultivation should mediate racial/ethnic differentials in children's learning even after SES is controlled (see also Pattillo- McCoy 1999).

\section{Data and Methods}

\section{Data}

The data used for the analysis came from the ongoing ECLS-K, a unique nationally representative data source that was designed to study social-group (i.e., race/ethnicity and socioeconomic background) differences in children's socioemotional and cognitive development. The ECLS-K data were collected by the National Center for Education Statistics (NCES 2000, 2004) using a threestage stratified sampling procedure. A sample of approximately 23 children from each of more than 1,000 public and private schools offering kindergarten programs was selected from a sample of geographic areas consisting of a county or groups of 
counties. Information was gathered from the children, their families, teachers, and school administrators, making the ECLS-K one of the best designed data sources for the analysis of children's early educational development. The achievement analyses presented later were based on a multiple-imputation analysis of missing data to maximize the sample sizes (Allison 2001; Little and Rubin 1987). The mathematics sample contained 14,579 children who were assessed at 59,241 person-periods, while the reading sample contained 14,544 children who were assessed at 57,472 person-periods.

\section{Control Variables}

Descriptive statistics using the parent-child population weights for the sample are presented in Table 1 . The approximate nonmissing sample size at kindergarten entry is 14,152 cases, although it should be noted that this wave-specific sample size fluctuated owing to sample refreshing, a restricted 20 percent subsample in the fall of first grade, and family mobility and attrition. The sample was approximately 60 percent white, 13 percent black, 17 percent Hispanic, 5 percent Asian, and 5 percent "other." SES is a standardized measure composed of parental occupation, education, and income.

The family context variables that were used in the later regression analyses are included in the table. The child's age in months at kindergarten entry was adjusted for because older children have had more time to learn and mature (Burkam et al. 2004; Downey et al. 2004; Reardon 2003). Additional covariates included whether the child was female and whether the child was a second-time kindergartner.

Because the analysis included heterogeneous groupings, such as Hispanic and Asian, who were likely to be from immigrant families, whether a non-English language was spoken at home was constructed to differentiate these children, who might not have been able to get help with English-based mathematics and reading skills at home. Family structure has been shown to be related to children's academic success and to both race and socioeconomic background (Teachman 2000). Two- parent, continuously married, families represent the comparison group, with additional categorizations comprising the stepparent family (either the mother or father but mostly the stepfather), the single-parent family (mostly the single mother), and an other category comprised of children living with their grandparents and other miscellaneous groupings. In addition, a child to adult ratio (centered at 1 ) is also included to adjust for family size and the dilution of resources (Downey 1995).

Older mothers are likely to have more stable employment and to have more life experience and greater maturity. The mother's age at kindergarten entry is lower for more disadvantaged groups. This variable is centered at the sample grand mean (33.2 years) in subsequent analyses. The mother's employment status is also included, with full-time employment the baseline category. The indicator categories are mother works part time and mother does not work. Across all racial/ethnic categories, mothers are most likely to work part time. In addition, whether the mother worked prior to the child's birth is included.

Parents' educational aspirations for their children, a proxy for parents' academic orientations, have been found to be related to children's later academic achievement. More than a high school education but less than a graduate degree is the reference category, with indicators for expectations for a high school degree or less or a graduate degree or higher included in the analysis. Children's early experiences differ with respect not only to their home environments, but to preschooling experiences. No care is the reference category, with home-based care, Head Start, and center-based care coded as dummy variables.

\section{Concerted Cultivation}

The underlying patterns of parental educational investment that Lareau (2003) reported are identified using measures of the organization of children's daily lives, use of language, and parental interventions with institutions. Parents who practiced concerted cultivation used formal activities with professionals and adults to structure their children's 


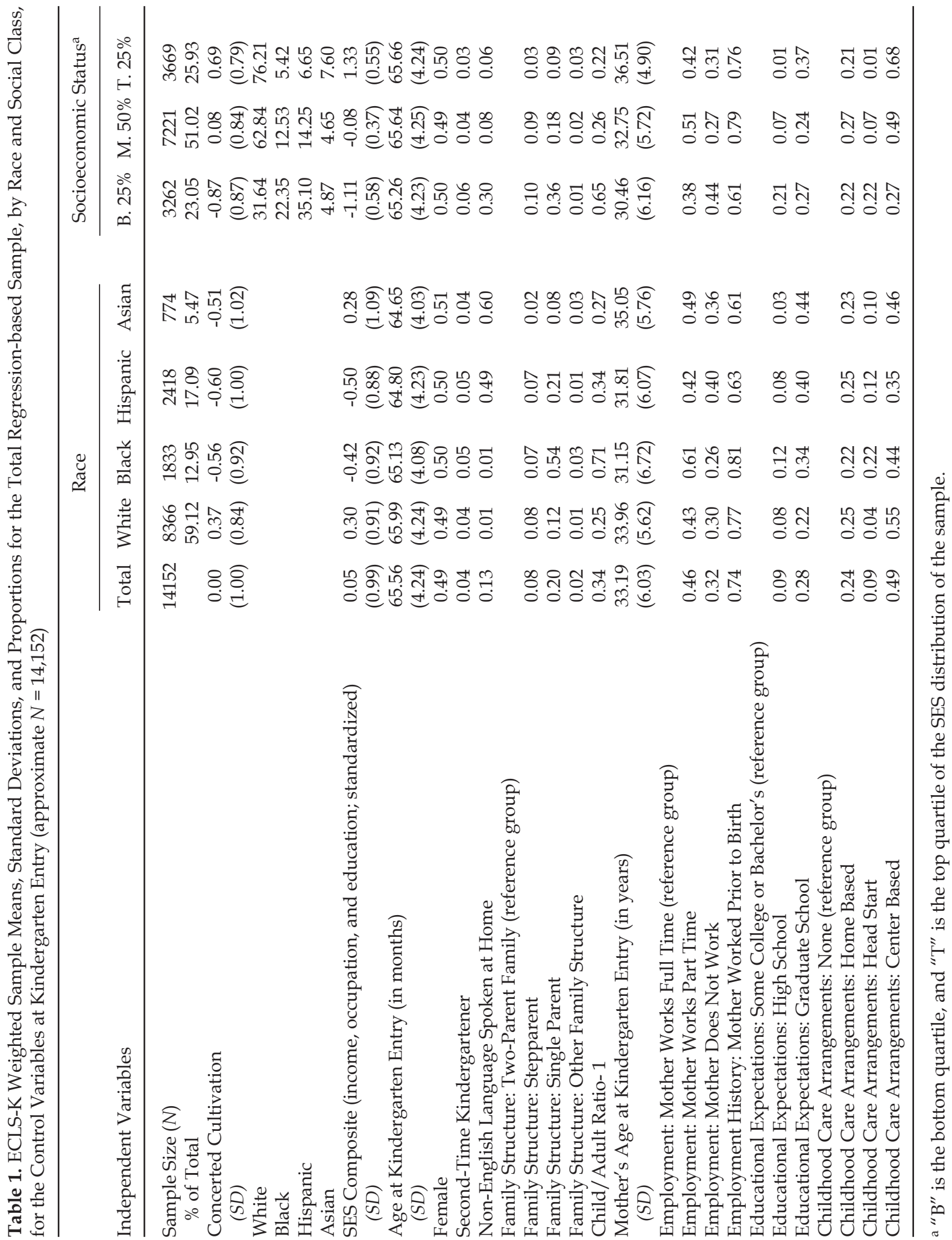


time and to supply access to various experiences to afford children with training for school success.

Concerted cultivation is modeled as a secondorder factor structure, as depicted in Figure 1, while posterior factor-score estimates are used in the subsequent analyses of growth in achievement. Concerted cultivation, the most general factor, is related to observations through an intermediate factor structure reflecting the dimensions that Lareau (2003) discussed. The child activities dimension is identified using indicators of whether the child has ever, outside school hours, participated in (1) dance lessons, (2) organized athletic activities, (3) clubs or recreational programs, (4) music lessons, (5) art classes or lessons, and (6) organized performing arts programs. ${ }^{1}$ Similarly, parental involvement with the school is identified with six dichotomous indicators asking whether any of the adults in the household have, within the past year, (1) attended an open house or back-to-school night, (2) attended a PTA or PTO meeting, (3) been to a regularly scheduled parent-teacher conference with the child's teacher, (4) attended a school or class event, (5) volunteered at school or served on a committee, and (6) participated in a school fund-raiser.

There is no direct measure of the ways in which parents speak to their children (e.g., use of directives, reasoning, or negotiation) and no direct cognitive information, such as scores on IQ tests for parents. Although the lack of these measures represents a potential gap in the ability to capture fully an important dimension of concerted cultivation, it is possible to identify other material resources in the home. Maternal ability (e.g., the Air Force Qualification Test) has been shown to operate at least partially through cognitive stimulation (Guo and Harris 2000). Lareau (2003) noted the differential availability of learning materials in concerted cultivation-practicing families, particularly the extent to which parents seek to cultivate children's interests by seeking out materials - although the disparity in learning resources is likely to be a function of financial resources, too (Chin and Phillips 2004). Although questions about the presence of newspapers and other reading materials in the home were asked in later waves, these variables are not avail- able for the earlier assessments. ${ }^{2}$ The number of the child's books is the best measure of material academic resources available across the waves. ${ }^{3}$

The measure of the concerted-cultivation pattern of parental educational investment follows that developed by Cheadle (2005) and Cheadle and Amato (2007), which used an admixture of item response theory (IRT; De Boeck and Wilson 2004; van der Linden and Hambleton 1997) and classical structural equation modeling approaches to confirmatory factor analysis (CFA; Bollen 1989; Muthén and Muthén 2004). These studies found that, cross sectionally, the concerted cultivation CFA fit the data well by normative standards (RMSEA $=.025$, CFI $=.951$, TLI $\left.=.961, x^{2}=483.6, d f=44, \mathrm{a}=.97\right)$. Furthermore, a three-wave model with time points in the spring of kindergarten and third grade fit similarly well $($ RMSEA $=.025, \mathrm{CFI}=.947$, TLI $=.967$, $\left.x^{2}=1,763, d f=150\right)$, with across-wave correlations ranging from .94 to .98 . The three-wave model also showed that the factor loadings between concerted cultivation and the three subdimensions were largely invariant over this period and that although there was some movement in the loadings relating the items to the subdimensions, substantively, the factor structure was relatively invariant over the period. Taken together, these results indicate that a continuous or gradational model that is predicated on Lareau's (2003) observations fits the data well cross sectionally and longitudinally and that the construct is stable over time.

\section{Math and Reading Achievement}

The math and reading analyses use IRT scaled scores so that children's assessments can be equated over time. The assessments ${ }^{4}$ evaluate children across a number of content strands using adaptive testing methods that allowed the tests to be tailored to children. Over the study period, the mathematics areas included number sense, properties, and operations; measurement; geometry and spatial sense; data analysis; statistics; and probability, patterns, algebra, and functions. The largest category of time spent on items across waves was drawn from number sense, properties, and operations. The reliabili- 


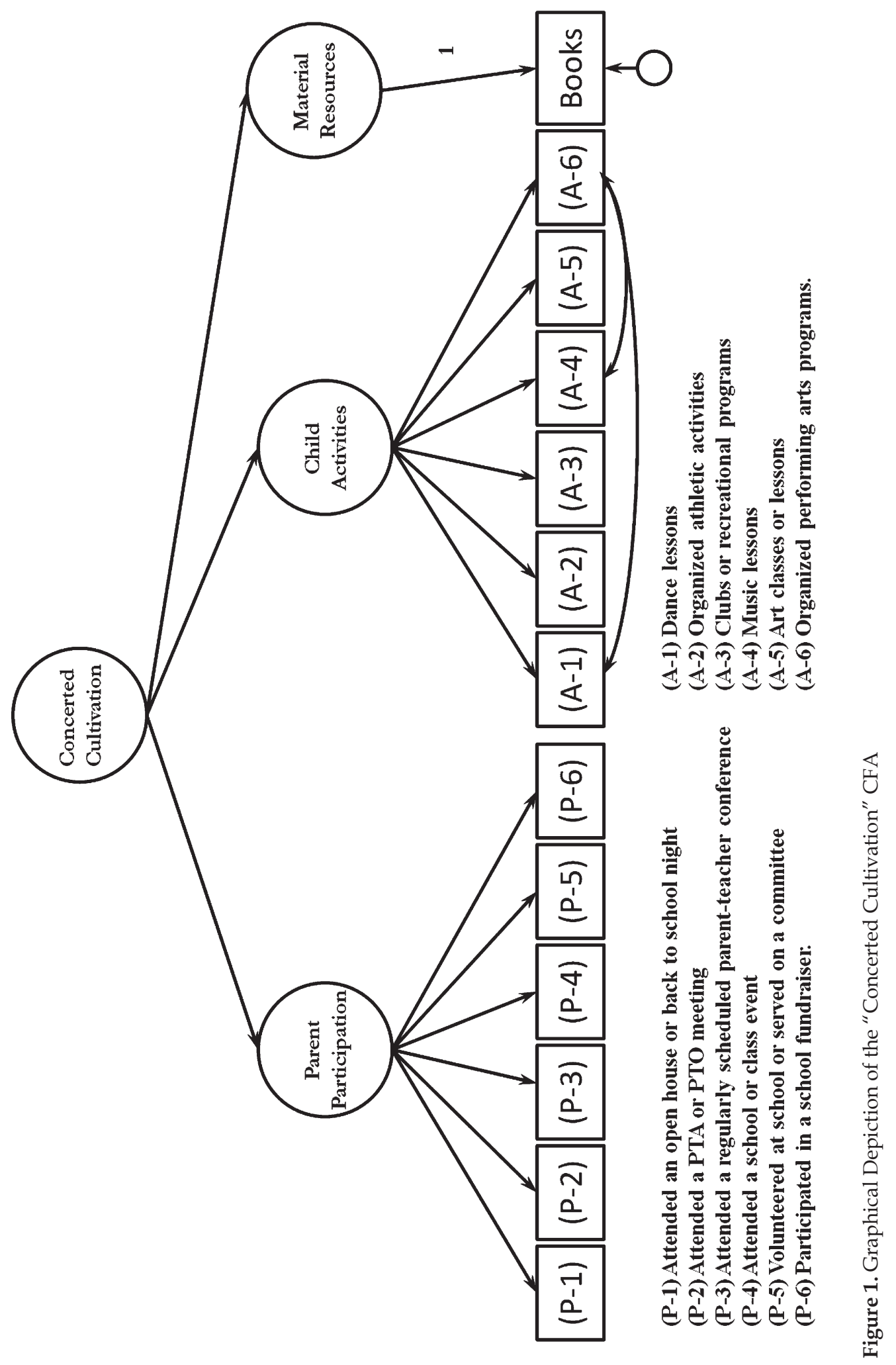


ties across the first four waves of data ranged from .92 to .94 .

The reading battery assessed children across numerous content strands, including initial understanding, developing interpretation, personal reflection and response, and demonstrating a critical stance. Over the first four waves, the reliability estimates ranged from .93 to .97 . The reading assessments were further complicated because of language issues for Hispanic children. The ECLSK administered the Oral Language Development Scale (OLDS) to assess children who had a nonEnglish-language background. Only children who passed the OLDs were administered the reading test, so the sample at each given wave is representative only of those who showed a basic level of English competency (for mathematics, the children were given an alternative Spanish translation).

\section{Analytic Methods}

The basic structure of the achievement model was drawn from the familiar multilevel random-effects or hierarchical linear model (HLM; Raudenbush and Bryk 2002; Singer and Willett 2003; for additional information on the piecewise structure, see Downey et al. 2004; March and Cormier 2002; Reardon 2003). The Level 1 within-student model, in which $t$ indexes within-student observations, $i$ indexes students or the between-student part of the model, and $j$ indexes schools, is defined as

$$
\mathrm{Y}_{\mathrm{tij}}=\pi_{0 \mathrm{ij}}+\pi_{1 \mathrm{ij}} \mathrm{K}_{\mathrm{tij}}+\pi_{2 \mathrm{ij}} \mathrm{S}_{\mathrm{tij}}+\pi_{3 \mathrm{tj}} \mathrm{F}_{\mathrm{tij}}+\pi_{4 \mathrm{ij}} \mathrm{T}_{\mathrm{tij}}+\varepsilon_{\mathrm{tij}}
$$

and the Level 2 between-student model, where the $\pi p i j$ are rates representing points gained per month, is defined as

$$
\pi_{p i j}=\beta_{p 0 j}+\sum_{q=1}^{Q} \beta_{p q j}\left(X_{q(t) i j}-\bar{X}_{q(t) j}\right)+\eta_{p i j}^{(2)}
$$

and the Level 3 between-school model is defined as

$$
\begin{aligned}
& \beta_{p 0 j}=Y_{p 00}+\eta_{p j}{ }^{(3)} \\
& \beta_{p q j}=Y_{p q 0}
\end{aligned}
$$

where $K$ is time in kindergarten, $S$ is summer duration, $F$ is time in the first grade, and $T$ is the length of time from the first grade to the third-grade assessment (for details on the creation of the timing variables, see Reardon 2003). Growth during $K$ and $F$ is interpreted in reference to points gained per month during the school year, $S$ captures points per month during the summer when school is not in session, and $T$ represents average growth per month between the spring of the first and third grades. ${ }^{5}$

The model is presented graphically in Figure 2, where it can be seen that children are allowed to grow at distinctive rates over different periods of their early schooling careers. ${ }^{6}$ Initial status and the temporal slopes are allowed to vary between students and schools, conditioned on between-student variables $X_{q(t) i j}$ (e.g., slopes as outcomes). The Level 2 between-child covariates are included as timechanging covariates $[(t)]$ specific to the period. Including time-varying covariates as predictors of the growth parameters is possible because the piecewise approach breaks the timeline into meaningful segments. The $\eta(l)$ represent random effects or deviations at Level $l$ and are assumed $M V N(\mathbf{0}, \boldsymbol{\Psi}(l))$ within level and orthogonal across levels. In addition, because there are up to five observations per child and five child-level random effects, the Level 1 variance is fixed using precision weights to identify the model. ${ }^{7}$

Coefficient estimates in these models, however, can be biased if the between student variables $X_{q(t) i j}$ are correlated with the random effects, $\eta(3)$, in other words, if there is a significant between-school relationship between the growth in average test scores and group means that are not accounted for. To eliminate this source of bias (see Raudenbush and Bryk 2002, chap. 5), the between-child covariates are centered around their school means, $\bar{X}_{q(t) j}$. This centering strategy results in parameter estimates that reflect average differences among children in the same schools, adjusting for temporally constant school-level sources of variation. ${ }^{8}$

Because the growth model estimates period-specific parameters, a covariate is included for whether a child moved over a given period. ${ }^{9}$ In addition, the analyses are based on five multiple-imputation 


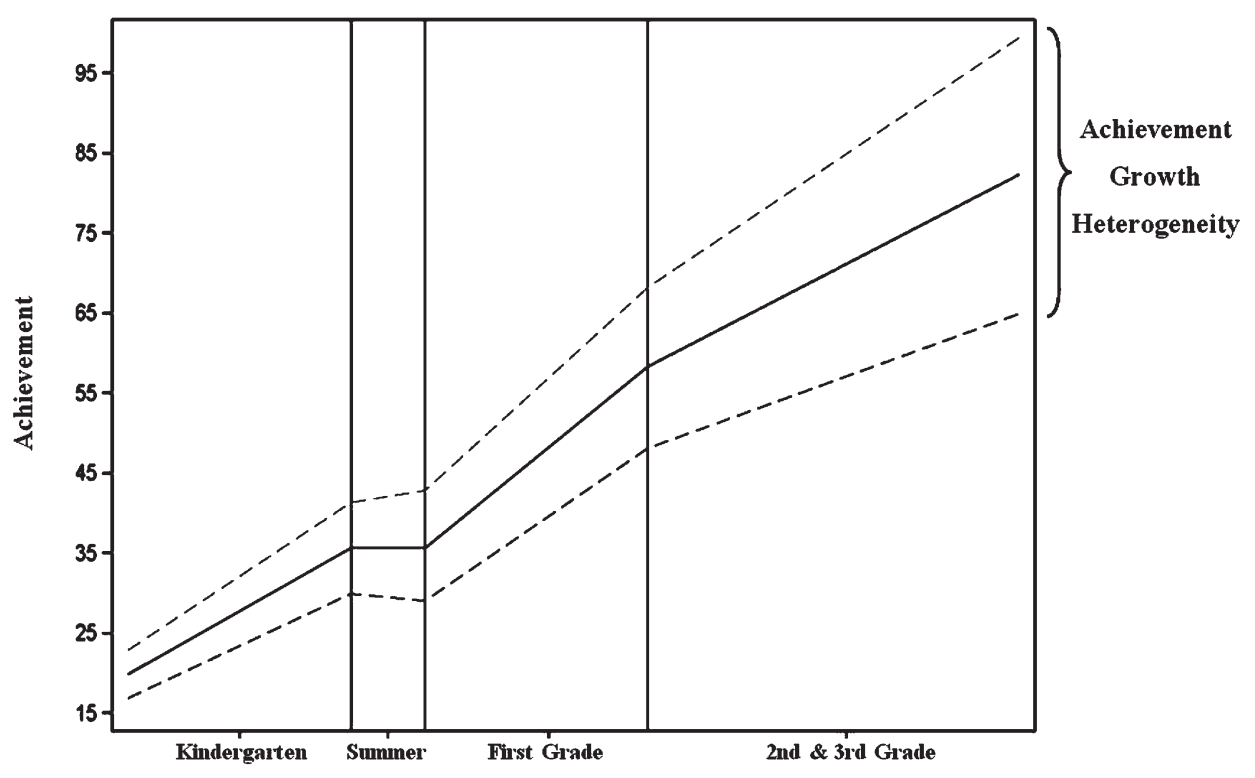

Figure 2. Graphical Depiction of the Model of Growth in Children's Academic Achievement

data sets (Allison 2001; Little and Rubin 1987) for both dependent variables. ${ }^{10}$ Imputation was done as a flat file with wave-specific variables that were distributed as the columns (see Allison 2001), including the dependent variables and weights. Imputed values for the dependent variable, however, were not included in the analysis (see Downey et al. 2004:619). Sample sizes increased from a maximum of 11,000 cases to more than 14,500 . The sample sizes vary with outcome, however, so the exact numbers are reported in the tables.

\section{Plan of Analysis}

Parameter estimates for the descriptive and explanatory three-level growth models are presented in Table 2 for mathematics and Table 4 for reading. The full-model series is presented to illuminate the following research questions: whether concerted cultivation is related to children's academic skills at kindergarten entry and subsequent growth after entering school, which are addressed descriptively in Model A. Model series B and C assess the extent to which the concerted-cultivation pattern of educational investment plays a role in socioeconomic gaps in children's learning. In addition, Lareau (2003) suggested that concerted cultivation should not be significantly associated with racial/ethnic differences in children's learning after socioeconomic or social-class background are adjusted for. This question is addressed in Models D-G. Growth equations that include the dummy variables for race/ethnicity appear in Model D, SES is added to Model E, concerted cultivation is in Model F, and both are included in Model G. Of primary interest is the change in the racial/ethnic coefficients between $D$ and $E$ and then $E$ and $G$, while $F$ is included to illustrate the meditational role played by concerted cultivation relative to socioeconomic background. Parameter estimates for the concerted-cultivation measure, social background, and family context characteristics appear in Model $\mathrm{H}$, while the coefficients for the entire covariate list appear in Table 3 for math and Table 5 for reading.

As was mentioned earlier, Chin and Phillips (2004) challenged Lareau's (2003) assertion that parents enact different parenting strategies derived from class-based cultural logics of child rearing. They suggested that observed differences in parenting strategies reflect differences in resources 
like income and occupational flexibility. If measures of parental educational investments like concerted cultivation actually reflect differences in parental resources, rather than an enacted cultural logic of child rearing, the measure should differentially mediate the educational, income, and occupational components of parental socioeconomic background. Furthermore, according to Lareau's model, concerted cultivation should largely operate through parental education, while according to Chin and Phillips, the measure should also be strongly implicated in income and occupational differentials. School fixed-effects models at kindergarten entry disaggregating the socioeconomic composite used in the growth analysis and assessing the mediating role of the concerted cultivation and family context variables are presented in Appendix Table A1.

\section{Results}

\section{The Measure of Concerted Cultivation}

Descriptive statistics for the concerted-cultivation measure across racial/ethnic groups and socioeconomic strata are presented in Table 1. These statistics indicate that concerted cultivation is primarily a white and upperclass pattern of investment, with black, Hispanic, and Asian groups scoring between .5 and .6 standard deviations (SD) below the sample average, which is approximately $.9 S D$ lower than the average white family. LowerSES parents score approximately .9 SD lower than the average SES family, while upper-SES families score nearly .7 SD higher. Furthermore, according to Cheadle (2005) and Cheadle and Amato (2007), the racial/ethnic differences (.4-.6 SD) remain large even after socioeconomic background (.43 SD) and additional sociodemographic characteristics are controlled. These results indicate that racial/ethnic background is strongly related to the practice of concerted cultivation and that, contrary to Lareau (2003), the measure may play an important role in socioeconomic and racial/ethnic differences in children's learning.

\section{Mathematics Achievement}

The parameter estimates for mathematics growth appear in Table 2. Children learn math continually over the study period (Model A), with those from families practicing average levels of concerted cultivation scoring about 18 points at school entry (initial status), acquiring skills during the school year at a rate of about 1.2-2.4 points per month, and over the summer when out of school at a rate of approximately .53 points per month.

The Concerted Cultivation Gradient The concerted cultivation measure of parental educational investment is strongly related to children's math skills at kindergarten entry. The coefficient magnitude of approximately 2 points for each $S D$, an effect size of approximately $27 S D$ (relative to the within-school $S D$ ), is about 88 percent of the socioeconomic coefficient (Model B) magnitude. Although the coefficient is substantially reduced in magnitude ( $\approx 43$ percent) when the full covariate list is added to the equation (Model G), a nontrivial relationship persists across specifications. Early on, concerted cultivation is also related to children's growth rates, although the measure is not consistently associated with growth after the summer prior to the first grade across model specifications. Notably, children from concerted-cultivating families grow faster during the summer, with the average growth rates between children $1 S D$ of concerted cultivation apart differing by approximately 20 percent (Model G).

The Socioeconomic Gradient The socioeconomic gradient is also large (Model B), nearly 2.3 points for each $S D$ difference between students who attend the same school ( $\approx .3 S D$ relative to the withinschool SD). The role of concerted cultivation in mediating social-class differences in children's math skills at kindergarten entry is more modest than theory leads one to suspect, since the socioeconomic coefficient is reduced by just over 21 percent in Model C. Since these measures are highly collinear, disadvantage on one implies disadvantage on the other, resulting in a large combined socioeconomic and concerted-cultivation gradient on chil- 
Table 2. Group Mean-Centered Growth Models for Math Achievement (IRT) from Kindergarten Entry Until the Spring of Third Grade, Including Race, Family SES, "Concerted Cultivation," and Selected Covariates

\begin{tabular}{|c|c|c|c|c|c|c|c|c|}
\hline \multirow[b]{2}{*}{ Variables $^{\mathrm{a}}$} & \multicolumn{8}{|c|}{ Model } \\
\hline & A & B & C & $\mathrm{D}$ & $\mathrm{E}$ & $\mathrm{F}$ & G & $\mathrm{H}$ \\
\hline Initial Status & $\begin{array}{c}18.087^{* *} \\
(0.153)\end{array}$ & $\begin{array}{l}18.074^{\star *} \\
(0.153)\end{array}$ & $\begin{array}{l}18.081^{* *} \\
(0.153)\end{array}$ & $\begin{array}{l}18.081^{* *} \\
(0.153)\end{array}$ & $\begin{array}{l}18.078^{* *} \\
(0.153)\end{array}$ & $\begin{array}{l}18.092^{* *} \\
(0.153)\end{array}$ & $\begin{array}{l}18.085^{* *} \\
(0.153)\end{array}$ & $\begin{array}{c}18.083^{* *} \\
(0.153)\end{array}$ \\
\hline Black & & & & $\begin{array}{l}-2.468^{* *} \\
(0.312)\end{array}$ & $\begin{array}{l}-1.748^{* *} \\
(0.302)\end{array}$ & $\begin{array}{l}-1.550^{* *} \\
(0.309)\end{array}$ & $\begin{array}{l}-1.225^{* *} \\
(0.306)\end{array}$ & $\begin{array}{l}-1.034^{* *} \\
(0.313)\end{array}$ \\
\hline Hispanic & & & & $\begin{array}{l}-3.276^{* *} \\
(0.257)\end{array}$ & $\begin{array}{l}-2.370^{* *} \\
(0.252)\end{array}$ & $\begin{array}{l}-2.179^{* *} \\
(0.259)\end{array}$ & $\begin{array}{l}-1.794^{* *} \\
(0.256)\end{array}$ & $\begin{array}{l}-1.518^{* *} \\
(0.269)\end{array}$ \\
\hline Asian & & & & $\begin{array}{c}0.339^{*} \\
(0.367)\end{array}$ & $\begin{array}{c}0.361 \\
(0.352)\end{array}$ & $\begin{array}{l}1.694^{* *} \\
(0.363)\end{array}$ & $\begin{array}{l}1.309^{* *} \\
(0.362)\end{array}$ & $\begin{array}{l}1.623^{* *} \\
(0.384)\end{array}$ \\
\hline Other race & & & & $\begin{array}{l}-1.239 * * \\
(0.381)\end{array}$ & $\begin{array}{l}-0.841^{*} \\
(0.371)\end{array}$ & $\begin{array}{l}-0.664 \\
(0.376)\end{array}$ & $\begin{array}{l}-0.516 \\
(0.371)\end{array}$ & $\begin{array}{l}-0.364 \\
(0.370)\end{array}$ \\
\hline SES & & $\begin{array}{c}2.256^{* *} \\
(0.089)\end{array}$ & $\begin{array}{l}1.776^{* *} \\
(0.094)\end{array}$ & & $\begin{array}{l}2.098^{* *} \\
(0.089)\end{array}$ & & $\begin{array}{l}1.654^{* *} \\
(0.095)\end{array}$ & $\begin{array}{l}1.386^{* *} \\
(0.098)\end{array}$ \\
\hline Concerted cultivation & $\begin{array}{l}1.973^{* *} \\
(0.088)\end{array}$ & & $\begin{array}{l}1.392^{* *} \\
(0.092)\end{array}$ & & & $\begin{array}{l}1.880^{* *} \\
(0.090)\end{array}$ & $\begin{array}{l}1.354^{* *} \\
(0.094)\end{array}$ & $\begin{array}{l}1.127^{* *} \\
(0.098)\end{array}$ \\
\hline Kindergarten Slope & $\begin{array}{l}1.657^{* *} \\
(0.014)\end{array}$ & $\begin{array}{l}1.655^{\star *} \\
(0.014)\end{array}$ & $\begin{array}{l}1.656^{* *} \\
(0.014)\end{array}$ & $\begin{array}{l}1.655^{* *} \\
(0.014)\end{array}$ & $\begin{array}{l}1.655^{* *} \\
(0.014)\end{array}$ & $\begin{array}{l}1.656^{* *} \\
(0.014)\end{array}$ & $\begin{array}{l}1.656^{* *} \\
(0.014)\end{array}$ & $\begin{array}{l}1.656^{* *} \\
(0.014)\end{array}$ \\
\hline Black & & & & $\begin{array}{l}-0.281^{* *} \\
(0.039)\end{array}$ & $\begin{array}{l}-0.240^{* *} \\
(0.039)\end{array}$ & $\begin{array}{l}-0.239^{* *} \\
(0.040)\end{array}$ & $\begin{array}{l}-0.222^{* *} \\
(0.040)\end{array}$ & $\begin{array}{l}-0.218^{* *} \\
(0.041)\end{array}$ \\
\hline Hispanic & & & & $\begin{array}{l}-0.142^{* *} \\
(0.033)\end{array}$ & $\begin{array}{l}-0.096^{* *} \\
(0.033)\end{array}$ & $\begin{array}{l}-0.092^{* *} \\
(0.033)\end{array}$ & $\begin{array}{l}-0.072^{*} \\
(0.033)\end{array}$ & $\begin{array}{l}-0.060 \\
(0.035)\end{array}$ \\
\hline Asian & & & & $\begin{array}{l}-0.030 \\
(0.047)\end{array}$ & $\begin{array}{l}-0.036 \\
(0.046)\end{array}$ & $\begin{array}{c}0.037 \\
(0.048)\end{array}$ & $\begin{array}{c}0.018 \\
(0.048)\end{array}$ & $\begin{array}{c}0.040 \\
(0.050)\end{array}$ \\
\hline Other race & & & & $\begin{array}{l}-0.140^{* *} \\
(0.049)\end{array}$ & $\begin{array}{l}-0.118^{*} \\
(0.048)\end{array}$ & $\begin{array}{l}-0.112^{*} \\
(0.049)\end{array}$ & $\begin{array}{l}-0.104^{*} \\
(0.049)\end{array}$ & $\begin{array}{l}-0.096^{*} \\
(0.049)\end{array}$ \\
\hline SES & & $\begin{array}{c}0.116^{* *} \\
(0.011)\end{array}$ & $\begin{array}{l}0.094^{* *} \\
(0.012)\end{array}$ & & $\begin{array}{c}0.106^{* *} \\
(0.012)\end{array}$ & & $\begin{array}{c}0.087^{* *} \\
(0.012)\end{array}$ & $\begin{array}{l}0.072^{* *} \\
(0.013)\end{array}$ \\
\hline Concerted cultivation & $\begin{array}{c}0.095^{* *} \\
(0.011)\end{array}$ & & $\begin{array}{l}0.065^{* *} \\
(0.012)\end{array}$ & & & $\begin{array}{c}0.087^{* *} \\
(0.012)\end{array}$ & $\begin{array}{l}0.060^{* *} \\
(0.012)\end{array}$ & $\begin{array}{l}0.058^{* *} \\
(0.013)\end{array}$ \\
\hline Summer Slope & $\begin{array}{l}0.533^{* *} \\
(0.055)\end{array}$ & $\begin{array}{l}0.532 * * \\
(0.055)\end{array}$ & $\begin{array}{l}0.533^{* *} \\
(0.055)\end{array}$ & $\begin{array}{l}0.533^{* *} \\
(0.055)\end{array}$ & $\begin{array}{c}0.532^{* *} \\
(0.055)\end{array}$ & $\begin{array}{c}0.534^{* *} \\
(0.055)\end{array}$ & $\begin{array}{c}0.534^{* *} \\
(0.055)\end{array}$ & $\begin{array}{l}0.534^{* *} \\
(0.055)\end{array}$ \\
\hline Black & & & & $\begin{array}{l}-0.097 \\
(0.173)\end{array}$ & $\begin{array}{l}-0.073 \\
(0.174)\end{array}$ & $\begin{array}{l}-0.040 \\
(0.174)\end{array}$ & $\begin{array}{l}-0.035 \\
(0.175)\end{array}$ & $\begin{array}{l}-0.038 \\
(0.178)\end{array}$ \\
\hline Hispanic & & & & $\begin{array}{c}0.033 \\
(0.153)\end{array}$ & $\begin{array}{c}0.061 \\
(0.153)\end{array}$ & $\begin{array}{c}0.095 \\
(0.155)\end{array}$ & $\begin{array}{c}0.102 \\
(0.155)\end{array}$ & $\begin{array}{c}0.088 \\
(0.161)\end{array}$ \\
\hline Asian & & & & $\begin{array}{c}0.529^{*} \\
(0.218)\end{array}$ & $\begin{array}{c}0.544^{*} \\
(0.218)\end{array}$ & $\begin{array}{l}0.625^{* *} \\
(0.222)\end{array}$ & $\begin{array}{l}0.625^{* *} \\
(0.222)\end{array}$ & $\begin{array}{c}0.589^{*} \\
(0.234)\end{array}$ \\
\hline Other race & & & & $\begin{array}{l}-0.007 \\
(0.210)\end{array}$ & $\begin{array}{c}0.020 \\
(0.210)\end{array}$ & $\begin{array}{c}0.038 \\
(0.211)\end{array}$ & $\begin{array}{c}0.039 \\
(0.211)\end{array}$ & $\begin{array}{c}0.042 \\
(0.212)\end{array}$ \\
\hline SES & & $\begin{array}{c}0.069 \\
(0.054)\end{array}$ & $\begin{array}{c}0.039 \\
(0.056)\end{array}$ & & $\begin{array}{c}0.068 \\
(0.054)\end{array}$ & & $\begin{array}{c}0.029 \\
(0.057)\end{array}$ & $\begin{array}{c}0.035 \\
(0.058)\end{array}$ \\
\hline Concerted cultivation & $\begin{array}{c}0.103^{*} \\
(0.052)\end{array}$ & & $\begin{array}{c}0.091 \\
(0.055)\end{array}$ & & & $\begin{array}{c}0.122^{*} \\
(0.053)\end{array}$ & $\begin{array}{r}0.113^{*} \\
(0.056)\end{array}$ & $\begin{array}{c}0.115^{*} \\
(0.058)\end{array}$ \\
\hline
\end{tabular}


Table 2. Continued

\begin{tabular}{|c|c|c|c|c|c|c|c|c|}
\hline \multirow[b]{2}{*}{ Variables $^{\mathrm{a}}$} & \multicolumn{7}{|c|}{ Model } & \multirow[b]{2}{*}{$\mathrm{H}$} \\
\hline & A & B & C & D & E & $F$ & G & \\
\hline First-Grade Slope & $\begin{array}{l}2.401^{* *} \\
(0.022)\end{array}$ & $\begin{array}{l}2.400^{* *} \\
(0.022)\end{array}$ & $\begin{array}{l}2.401^{* *} \\
(0.022)\end{array}$ & $\begin{array}{l}2.400^{* *} \\
(0.022)\end{array}$ & $\begin{array}{l}2.400^{* *} \\
(0.022)\end{array}$ & $\begin{array}{l}2.400^{* *} \\
(0.022)\end{array}$ & $\begin{array}{l}2.400^{* *} \\
(0.022)\end{array}$ & $\begin{array}{l}2.401^{* *} \\
(0.022)\end{array}$ \\
\hline Black & & & & $\begin{array}{l}-0.248^{* *} \\
(0.063)\end{array}$ & $\begin{array}{l}-0.223^{* *} \\
(0.063)\end{array}$ & $\begin{array}{l}-0.221^{* *} \\
(0.064)\end{array}$ & $\begin{array}{l}-0.206^{* *} \\
(0.064)\end{array}$ & $\begin{array}{l}-0.189^{*} \\
(0.065)\end{array}$ \\
\hline Hispanic & & & & $\begin{array}{l}-0.175^{* *} \\
(0.054)\end{array}$ & $\begin{array}{l}-0.137^{*} \\
(0.055)\end{array}$ & $\begin{array}{l}-0.140^{*} \\
(0.055)\end{array}$ & $\begin{array}{l}-0.121^{*} \\
(0.055)\end{array}$ & $\begin{array}{l}-0.124^{*} \\
(0.058)\end{array}$ \\
\hline Asian & & & & $\begin{array}{l}-0.287^{* *} \\
(0.078)\end{array}$ & $\begin{array}{l}-0.279 * * \\
(0.077)\end{array}$ & $\begin{array}{l}-0.246^{* *} \\
(0.079)\end{array}$ & $\begin{array}{l}-0.265^{* *} \\
(0.079)\end{array}$ & $\begin{array}{l}-0.273^{* *} \\
(0.083)\end{array}$ \\
\hline Other race & & & & $\begin{array}{l}-0.158^{*} \\
(0.077)\end{array}$ & $\begin{array}{l}-0.151^{*} \\
(0.077)\end{array}$ & $\begin{array}{l}-0.143 \\
(0.078)\end{array}$ & $\begin{array}{l}-0.133 \\
(0.078)\end{array}$ & $\begin{array}{l}-0.122 \\
(0.078)\end{array}$ \\
\hline SES & & $\begin{array}{l}0.098^{* *} \\
(0.019)\end{array}$ & $\begin{array}{l}0.082^{* *} \\
(0.020)\end{array}$ & & $\begin{array}{l}0.088^{* *} \\
(0.019)\end{array}$ & & $\begin{array}{l}0.081^{* *} \\
(0.020)\end{array}$ & $\begin{array}{l}0.061^{* *} \\
(0.021)\end{array}$ \\
\hline Concerted cultivation & $\begin{array}{l}0.072^{* *} \\
(0.019)\end{array}$ & & $\begin{array}{l}0.045^{*} \\
(0.020)\end{array}$ & & & $\begin{array}{l}0.054^{* *} \\
(0.019)\end{array}$ & $\begin{array}{c}0.028 \\
(0.020)\end{array}$ & $\begin{array}{c}0.030 \\
(0.021)\end{array}$ \\
\hline Second-Third-Grade Slope & $\begin{array}{l}1.193^{* *} \\
(0.007)\end{array}$ & $\begin{array}{l}1.193^{* *} \\
(0.007)\end{array}$ & $\begin{array}{l}1.193^{* *} \\
(0.007)\end{array}$ & $\begin{array}{l}1.193^{* *} \\
(0.007)\end{array}$ & $\begin{array}{l}1.193^{* *} \\
(0.007)\end{array}$ & $\begin{array}{l}1.193^{* *} \\
(0.007)\end{array}$ & $\begin{array}{l}1.193^{* *} \\
(0.007)\end{array}$ & $\begin{array}{l}1.193^{* *} \\
(0.007)\end{array}$ \\
\hline Black & & & & $\begin{array}{l}-0.112^{* *} \\
(0.020)\end{array}$ & $\begin{array}{l}-0.098^{* *} \\
(0.020)\end{array}$ & $\begin{array}{l}-0.110^{* *} \\
(0.020)\end{array}$ & $\begin{array}{l}-0.104^{* *} \\
(0.020)\end{array}$ & $\begin{array}{l}-0.096^{* *} \\
(0.020)\end{array}$ \\
\hline Hispanic & & & & $\begin{array}{l}-0.005 \\
(0.017)\end{array}$ & $\begin{array}{c}0.009 \\
(0.017)\end{array}$ & $\begin{array}{l}-0.003 \\
(0.017)\end{array}$ & $\begin{array}{c}0.005 \\
(0.017)\end{array}$ & $\begin{array}{l}-0.002 \\
(0.018)\end{array}$ \\
\hline Asian & & & & $\begin{array}{l}0.076^{* *} \\
(0.023)\end{array}$ & $\begin{array}{l}0.079 * * \\
(0.022)\end{array}$ & $\begin{array}{l}0.080^{* *} \\
(0.023)\end{array}$ & $\begin{array}{l}0.073^{* *} \\
(0.023)\end{array}$ & $\begin{array}{l}0.068^{* *} \\
(0.025)\end{array}$ \\
\hline Other race & & & & $\begin{array}{l}0.017 \\
(0.025)\end{array}$ & $\begin{array}{c}0.025 \\
(0.024)\end{array}$ & $\begin{array}{c}0.019 \\
(0.025)\end{array}$ & $\begin{array}{c}0.021 \\
(0.025)\end{array}$ & $\begin{array}{c}0.025 \\
(0.025)\end{array}$ \\
\hline SES & & $\begin{array}{l}0.031^{* *} \\
(0.006)\end{array}$ & $\begin{array}{l}0.033^{* *} \\
(0.006)\end{array}$ & & $\begin{array}{l}0.029 * * \\
(0.006)\end{array}$ & & $\begin{array}{l}0.030^{* *} \\
(0.006)\end{array}$ & $\begin{array}{l}0.023^{* *} \\
(0.006)\end{array}$ \\
\hline Concerted cultivation & $\begin{array}{c}0.005 \\
(0.006)\end{array}$ & & $\begin{array}{l}-0.006 \\
(0.006)\end{array}$ & & & $\begin{array}{c}0.005 \\
(0.006)\end{array}$ & $\begin{array}{l}-0.005 \\
(0.006)\end{array}$ & $\begin{array}{l}-0.004 \\
(0.006)\end{array}$ \\
\hline
\end{tabular}

${ }^{*} p<.05,{ }^{* *} p<.01$. Standard errors are in parentheses.

a The results and full covariate list for Model G are displayed in Table 3.

dren's math skills at kindergarten entry. As a measure of educational investment, however, concerted cultivation was expected to have the largest impact on socioeconomic differences in children's skill levels, which is not the case here. The socioeconomic gradient remains relatively large across model specifications, although the family context variables explain about another 17 percent of the gradient beyond concerted cultivation (from Model G to Model H).

Children from higher-SES families consistently grow at elevated rates after they enter school, acquiring more math skills than their lower-class schoolmates during kindergarten and the first, sec- ond, and third grades across model specifications, as shown in Figure 3. Concerted cultivation mediates between 19 percent and 16 percent of the socioeconomic advantage during kindergarten and the first grade, respectively, and is not implicated in the small gap in growth during the second and third grades. Furthermore, as Figure 3 shows, the socioeconomic gaps continue to grow when the full covariate list is included in the model.

Black-White Gap Black children, on average, enter kindergarten with scores approximately 2.5 points, or .34 SD, lower than those of white children. Approximately 30 percent of this gap results from the 

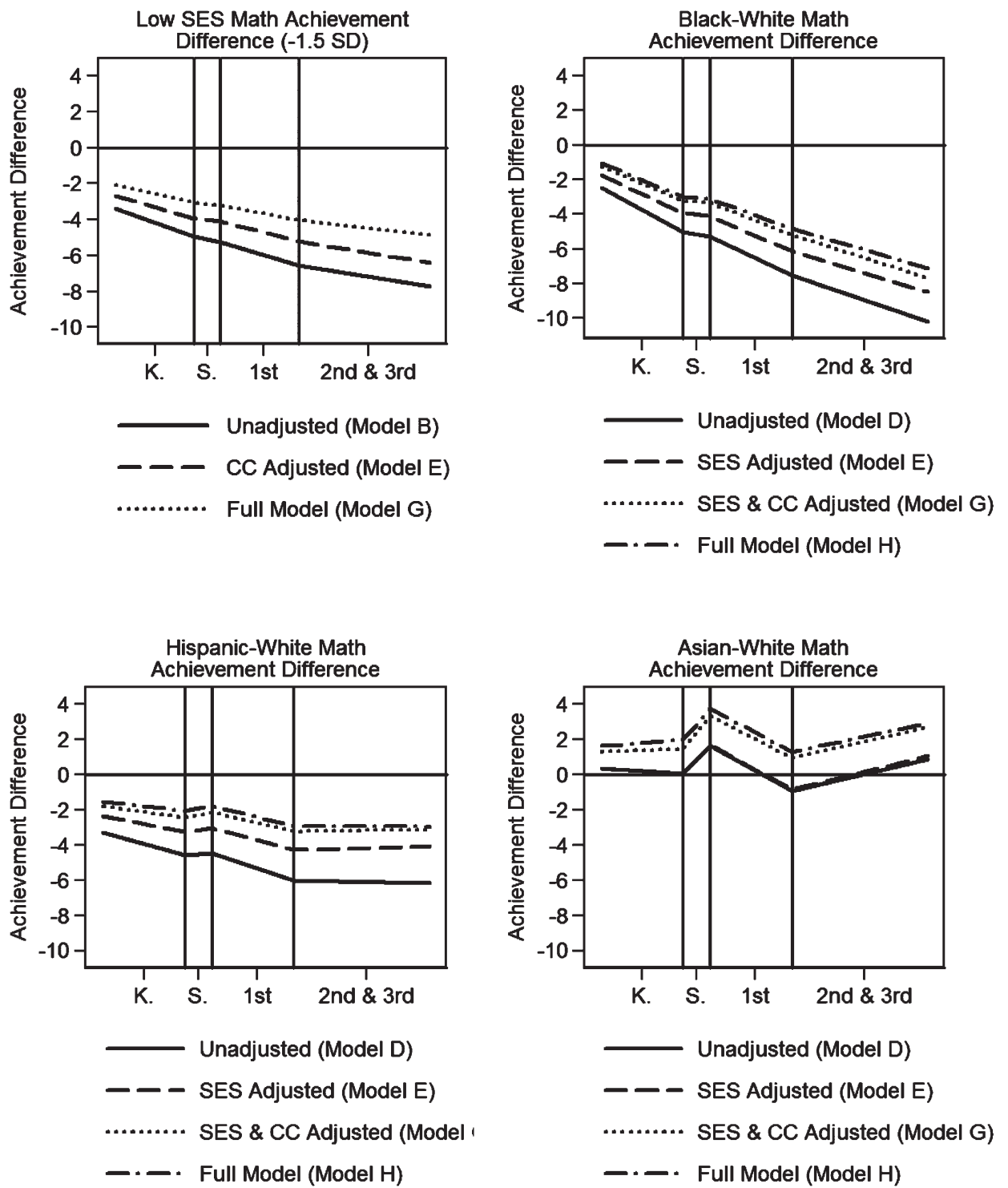

Figure 3. Graphical Depiction of the Growth in Disparities in Children's Math Achievement, by Family SES (-1.5 SD versus middle-SES children) and Race (black, Hispanic, and Asian versus white children)

poorer socioeconomic background of black children (Model E). Adding concerted cultivation to Model D (Model F) reduces the black-white gap by nearly 40 percent, although the difference remains statistically significant. However, even after socioeconomic background is controlled, concerted cultivation explains an additional 30 percent of the black-white gap (Models E and G), indicating the importance of parental educational investments above and beyond the socioeconomic component of the black-white gap.

As Figure 3 shows, black children grow more slowly during the primary grades than do their white schoolmates, although, in contrast to Entwisle and Alexander (1992), the gap does not widen during the summer. Furthermore, adding socioeconomic background, concerted cultivation, and the family context variables (Model $\mathrm{H}$ ) only minimally reduces 
during-school gaps in growth, suggesting that neither parental investments nor the indicators of family context are strongly implicated in black-white differences in achievement during the school year.

Hispanic-White Gap The average scores of Hispanic children are 3.3 points, or about $.45 S D$, lower than those of white children at kindergarten entry, or more than .8 points lower than those of black children. Socioeconomic background (Model E) explains 28 percent of this gap, while adding concerted cultivation to Model D (Model F) reduces the Hispanic-white disparity by more than 40 percent, reducing the Hispanic-white gap by an additional 24 percent above and beyond socioeconomic background (Model G versus Model E). The family context variables (Model $\mathrm{H}$ ), including whether a non-English language is spoken at home, further mediate the gap.

Hispanic children grow more slowly during kindergarten and the first grade, but grow at rates similar to those of white children over the summer and the second- to third-grade periods, as evidenced in Figure 3. Although the kindergarten growth gap remains significant after concerted cultivation is adjusted for, the differences in growth are reduced to nonsignificance after socioeconomic background and whether a non-English language is spoken at home are accounted for. Adding these additional controls does not reduce the first-grade disparity in growth to nonsignificance, although the overall reduction in the gap by the second grade, controlling for concerted cultivation and the full covariate list, is readily visible in Figure 3.

Asian-White Gap Asian and white children who attend the same schools do not have statistically different mathematics scores at kindergarten entry (Model D), although the Asian coefficient becomes large, positive, and statistically significant once concerted cultivation is added to the equation (Model F), suggesting that Asian children from families with the same level of concerted cultivation as their white schoolmates perform better, on average. Furthermore, the Asian advantage is relatively impervious to the control list once concerted cultivation is added to the equation. Perhaps the most striking finding is the large, positive growth rate of Asian children over the summer. On average, children acquire about .5 points per month, while Asian children grow at double the rate of other children. As Figure 3 shows, the Asian-white gap does not grow during kindergarten, decreases in the first grade, and grows over the second- to third-grade period, although this period is an admixture of two summers and two school years, so it is not clear if the previous findings are duplicated in this period. In addition, adjusting for the other covariates, including concerted cultivation, has little impact on the summer and school-year growth rate differentials.

Family Context Table 3 illustrates that other aspects of the family context are also related to children's early math achievement. Children who come from non-English-language homes score more than a point lower, adjusting for the full covariate list, at kindergarten entry. This model implies that the Hispanic coefficient for immigrant children is more than 2.5, rather than 1.5, points, since the estimated gap is the sum of the Hispanic and non-Englishlanguage coefficients. The scores of children from stepparent and single-parent families, although negative, are not statistically different from those of children in two-parent biological families, although children in homes with more children than adults score lower than do children from families with more favorable adult-child ratios. Children whose mothers are older also score higher, although children whose mothers work score lower, net of the other family context control variables, than children whose mothers work part time or do not work. Educational expectations are also associated with initial status, with low parental educational expectations associated with a .85-point decrement, and graduate school expectations associated with a nearly .7-point increment. Although Head Start was not associated with children's scores relative to having had no care, children who received some form of home-based care scored higher, while children who received center-based care had nearly a 1.3-point advantage.

There are few consistent relationships between the family context and children's growth after kindergarten entry. Low educational expectations are associated with decreased rates of growth during 
Table 3. Parameter Estimates for Model H from Table 2

\begin{tabular}{|c|c|c|c|c|c|}
\hline Variables & $\begin{array}{l}\text { Initial } \\
\text { Status }\end{array}$ & $\begin{array}{l}\text { Kindergarten } \\
\text { Slope }\end{array}$ & $\begin{array}{l}\text { Summer } \\
\text { Slope }\end{array}$ & $\begin{array}{l}\text { 1st-Grade } \\
\text { Slope }\end{array}$ & $\begin{array}{l}\text { 2nd-3rd Grade } \\
\text { Slope }\end{array}$ \\
\hline \multirow[t]{2}{*}{ Intercept } & $18.083^{* *}$ & $1.656^{* *}$ & $0.534^{* *}$ & $2.401^{* *}$ & $1.193^{* *}$ \\
\hline & $(0.153)$ & $(0.014)$ & $(0.055)$ & $(0.022)$ & $(0.007)$ \\
\hline \multirow[t]{2}{*}{ Black } & $-1.034^{* *}$ & $-0.218^{* *}$ & -0.038 & $-0.189 * *$ & $-0.096^{* *}$ \\
\hline & $(0.313)$ & $(0.041)$ & $(0.178)$ & $(0.065)$ & $(0.020)$ \\
\hline \multirow[t]{2}{*}{ Hispanic } & $-1.518^{* *}$ & -0.060 & 0.088 & $-0.124^{*}$ & -0.002 \\
\hline & $(0.269)$ & $(0.035)$ & $(0.161)$ & $(0.058)$ & $(0.018)$ \\
\hline \multirow[t]{2}{*}{ Asian } & $1.623^{* *}$ & 0.040 & $0.589 *$ & $-0.273^{* *}$ & $0.068^{* *}$ \\
\hline & $(0.384)$ & $(0.050)$ & $(0.234)$ & $(0.083)$ & $(0.025)$ \\
\hline \multirow[t]{2}{*}{ Other } & -0.364 & $-0.096^{*}$ & 0.042 & -0.122 & 0.025 \\
\hline & $(0.370)$ & $(0.049)$ & $(0.212)$ & $(0.078)$ & $(0.025)$ \\
\hline \multirow[t]{2}{*}{ Socioeconomic status } & $1.386^{* *}$ & $0.072^{* *}$ & 0.035 & $0.061^{* *}$ & $0.023^{* *}$ \\
\hline & $(0.098)$ & $(0.013)$ & $(0.058)$ & $(0.021)$ & $(0.006)$ \\
\hline \multirow[t]{2}{*}{ Concerted cultivation } & $1.127^{* *}$ & $0.058^{* *}$ & $0.115^{*}$ & 0.030 & -0.004 \\
\hline & $(0.098)$ & $(0.013)$ & $(0.058)$ & $(0.021)$ & $(0.006)$ \\
\hline Age at kindergarten entry & $\begin{array}{l}0.483^{* *} \\
(0.016)\end{array}$ & & & & \\
\hline \multirow[t]{2}{*}{ Female } & -0.157 & $-0.077^{* *}$ & 0.027 & $-0.128^{* *}$ & $-0.063^{* *}$ \\
\hline & $(0.138)$ & $(0.018)$ & $(0.082)$ & $(0.030)$ & $(0.009)$ \\
\hline \multirow{2}{*}{ Second-time kindergartner } & $-0.728^{*}$ & $-0.134^{* *}$ & -0.108 & -0.145 & $-0.098^{* *}$ \\
\hline & $(0.372)$ & $(0.047)$ & $(0.220)$ & $(0.078)$ & $(0.024)$ \\
\hline \multirow[t]{2}{*}{ Non-English language at home } & $-1.108^{* *}$ & -0.045 & 0.149 & -0.005 & 0.007 \\
\hline & $(0.290)$ & $(0.038)$ & $(0.175)$ & $(0.061)$ & $(0.019)$ \\
\hline \multirow[t]{2}{*}{ Stepparent } & -0.396 & -0.015 & 0.101 & -0.069 & 0.008 \\
\hline & $(0.279)$ & $(0.036)$ & $(0.140)$ & $(0.046)$ & $(0.015)$ \\
\hline \multirow[t]{2}{*}{ Single parent } & -0.385 & -0.026 & 0.088 & -0.024 & -0.020 \\
\hline & $(0.202)$ & $(0.026)$ & $(0.105)$ & $(0.036)$ & $(0.013)$ \\
\hline \multirow[t]{2}{*}{ Other family structure } & $-1.924^{* *}$ & $-0.148^{* *}$ & 0.059 & $-0.162^{*}$ & -0.005 \\
\hline & $(0.405)$ & $(0.052)$ & $(0.203)$ & $(0.071)$ & $(0.024)$ \\
\hline \multirow[t]{2}{*}{ Child/adult ratio -1} & $-0.453^{* *}$ & 0.010 & 0.035 & -0.010 & -0.007 \\
\hline & $(0.094)$ & $(0.012)$ & $(0.048)$ & $(0.017)$ & $(0.006)$ \\
\hline \multirow{2}{*}{ Mother's age (centered) } & $0.049 * *$ & 0.002 & 0.005 & 0.001 & $-0.002^{*}$ \\
\hline & $(0.013)$ & $(0.002)$ & $(0.007)$ & $(0.002)$ & $(0.001)$ \\
\hline \multirow[t]{2}{*}{ Mother works part time } & $0.554^{* *}$ & -0.002 & $0.157^{*}$ & -0.031 & 0.010 \\
\hline & $(0.189)$ & $(0.024)$ & $(0.078)$ & $(0.026)$ & $(0.011)$ \\
\hline \multirow[t]{2}{*}{ Mother does not work } & $0.482^{*}$ & -0.022 & -0.019 & -0.003 & -0.001 \\
\hline & $(0.199)$ & & & & \\
\hline \multirow[t]{2}{*}{ Mother worked before child's birth } & 0.053 & & & & \\
\hline & $(0.176)$ & $(0.022)$ & $(0.077)$ & $(0.025)$ & $(0.010)$ \\
\hline High school or less & & & & & \\
\hline educational expectations & $-0.850^{* *}$ & $-0.140^{* *}$ & 0.034 & $-0.214^{* *}$ & $-0.110^{* *}$ \\
\hline & $(0.258)$ & $(0.035)$ & $(0.113)$ & $(0.034)$ & $(0.016)$ \\
\hline Graduate school & & & & & \\
\hline educational expectations & $0.681^{* *}$ & 0.018 & -0.029 & 0.027 & $0.027^{*}$ \\
\hline & $(0.163)$ & $(0.021)$ & $(0.067)$ & $(0.023)$ & $(0.011)$ \\
\hline Home-based care & $0.582^{* *}$ & & & & \\
\hline & $(0.218)$ & & & & \\
\hline Head Start & 0.207 & & & & \\
\hline & $(0.288)$ & & & & \\
\hline Center-based care & $1.261^{* *}$ & & & & \\
\hline & $(0.190)$ & & & & \\
\hline Changed schools & & -0.033 & $0.305^{*}$ & -0.075 & -0.015 \\
\hline & & $(0.073)$ & $(0.113)$ & $(0.084)$ & $(0.012)$ \\
\hline Variance Components & & & & & \\
\hline Level 2 & $43.767^{* *}$ & $0.583^{* *}$ & $4.378^{* *}$ & $0.983^{* *}$ & $0.169^{* *}$ \\
\hline Level 3 & $17.749^{* *}$ & $0.114^{* *}$ & $0.526^{* *}$ & $0.159^{* *}$ & $0.025^{* *}$ \\
\hline
\end{tabular}

${ }^{*} p<.05,{ }^{* *} p<.01$. 
the school year, even after whether the child is a repeat kindergartner is adjusted for. A distressing finding is that girls grow slower than do boys during the school year, while children whose mothers work part time grow faster over the summer.

\section{Reading Achievement}

The same model-presentation sequence used for the mathematics analysis is used to relate children's growth in reading. Parameter estimates for descriptive and explanatory three-level growth models are presented in Table 4; parameter estimates for Model H, the full model, are displayed in Table 5; while graphical displays for the social-group gaps are omitted to preserve space and because, with the exception of the Asian-white gap, changes in the gaps are similar to those presented in the mathematics analysis.

Children from families who practice average levels of concerted cultivation (Model A) enter kindergarten (initial status) scoring about 23 points and grow during the school year at rates that are about 1.6-3.4 points per month. However, they lose ground over the summer at about .2 points per month.

The Concerted Cultivation Gradient The concertedcultivation measure, although not as strongly related to initial achievement as is socioeconomic background, is related to children's reading skills at kindergarten entry (Model A). The gradient suggests that two children who attend the same school but come from families whose practice of concerted cultivation differs by $1 S D$ are expected to have differences in scores of 2.2 points, or .26 SD (relative to the within-school, between-child $S D$ ). Although the magnitude is reduced by approximately 40 percent by Model $\mathrm{H}$, when the full covariate list is used, concerted cultivation remains an important predictor of children's reading skills at kindergarten entry.

A surprising finding is that concerted cultivation is not related to children's learning over the summer, although significantly different growth rates across model specifications are reported over kindergarten and the first grade. Although mediated by 67 percent over the kindergarten year and approximately 50 percent over the first grade when the full covariate list is incorporated (Model H), concerted cultivation remains a statistically significant predictor of children's growth, indicating that parental investments recoup small returns to children's learning during the school year, not only prior to entering school.

The Socioeconomic Gradient The socioeconomic gradient is also large, implying that the difference between two children who attend the same school and differ by 1 SD of SES will have scores that differ by more than 2.5 points, about 12 percent larger than the bivariate concerted-cultivation coefficient. In Model C, the social-class disparity is reduced to 2 points, a decrease of approximately 20 percent, suggesting that the concerted-cultivation pattern explains only a modest proportion of the socioeconomic advantage at kindergarten entry.

Children from advantaged socioeconomic backgrounds also acquire reading skills more quickly than their peers over kindergarten, the summer, and the first grade across equations. Concerted cultivation is only modestly implicated in the relationship between socioeconomic standing and kindergarten $(\approx 13$ percent) and first-grade learning $(\approx 22$ percent). Over the summer, children from higher socioeconomic backgrounds gain ground, while the average child (Model $\mathrm{H}$ ) looses approximately .18 points per month; children who are $1 S D$ above the mean have approximately no growth, while those from families that are $2 S D$ above the mean acquire .2 points per month. Notably, the concerted-cultivation pattern is not implicated in socioeconomic advantage over this period.

Black-White Gap Black children enter kindergarten scoring about 1.7 points lower than their white schoolmates, a difference of approximately .2 SD. Notably, the magnitude of the black coefficient decreases by nearly 47 percent when socioeconomic background is included (Model E). The gap decrease by 60 percent when concerted cultivation is added to the model (Model F), reducing the dispar- 
Table 4. Group Mean-Centered Growth Models for Reading Achievement (IRT) from Kindergarten Entry Until the Spring of Third Grade, Including Race, Family SES, "Concerted Cultivation," and Selected Covariates

\begin{tabular}{|c|c|c|c|c|c|c|c|c|}
\hline \multirow[b]{2}{*}{ Variables $^{a}$} & \multicolumn{8}{|c|}{ Model } \\
\hline & $\mathrm{A}$ & B & C & $\mathrm{D}$ & $\mathrm{E}$ & $\mathrm{F}$ & G & $\mathrm{H}$ \\
\hline Initial Status & $\begin{array}{c}23.236^{* *} \\
(0.162)\end{array}$ & $\begin{array}{l}23.226^{* *} \\
(0.161)\end{array}$ & $\begin{array}{c}23.234^{* *} \\
(0.161)\end{array}$ & $\begin{array}{c}23.217^{* *} \\
(0.162)\end{array}$ & $\begin{array}{l}23.220^{* *} \\
(0.161)\end{array}$ & $\begin{array}{c}23.233^{* *} \\
(0.162)\end{array}$ & $\begin{array}{c}23.229 * * \\
(0.161)\end{array}$ & $\begin{array}{c}23.220^{* *} \\
(0.162)\end{array}$ \\
\hline Black & & & & $\begin{array}{l}-1.724^{* *} \\
(0.370)\end{array}$ & $\begin{array}{l}-0.915^{*} \\
(0.356)\end{array}$ & $\begin{array}{l}-0.624 \\
(0.368)\end{array}$ & $\begin{array}{l}-0.254 \\
(0.365)\end{array}$ & $\begin{array}{l}-0.169 \\
(0.373)\end{array}$ \\
\hline Hispanic & & & & $\begin{array}{l}-2.957^{* *} \\
(0.308)\end{array}$ & $\begin{array}{l}-2.013^{* *} \\
(0.304)\end{array}$ & $\begin{array}{l}-1.774^{* *} \\
(0.309)\end{array}$ & $\begin{array}{l}-1.362^{* *} \\
(0.306)\end{array}$ & $\begin{array}{l}-1.113^{* *} \\
(0.316)\end{array}$ \\
\hline Asian & & & & $\begin{array}{c}1.099 * \\
(0.434)\end{array}$ & $\begin{array}{l}1.081^{* *} \\
(0.416)\end{array}$ & $\begin{array}{l}2.707^{* *} \\
(0.428)\end{array}$ & $\begin{array}{l}2.274^{* *} \\
(0.425)\end{array}$ & $\begin{array}{c}2.625^{* *} \\
(0.458)\end{array}$ \\
\hline Other race & & & & $\begin{array}{l}-0.886^{*} \\
(0.444)\end{array}$ & $\begin{array}{l}-0.434 \\
(0.435)\end{array}$ & $\begin{array}{l}-0.207 \\
(0.439)\end{array}$ & $\begin{array}{l}-0.039 \\
(0.434)\end{array}$ & $\begin{array}{c}0.091 \\
(0.432)\end{array}$ \\
\hline SES & & $\begin{array}{l}2.506^{* *} \\
(0.106)\end{array}$ & $\begin{array}{l}1.982^{* *} \\
(0.111)\end{array}$ & & & $\begin{array}{l}2.395^{* *} \\
(0.107)\end{array}$ & $\begin{array}{l}1.875^{* *} \\
(0.112)\end{array}$ & $\begin{array}{l}1.626^{* *} \\
(0.116)\end{array}$ \\
\hline Concerted cultivation & $\begin{array}{l}2.208^{* *} \\
(0.107)\end{array}$ & & $\begin{array}{l}1.564^{\text {** }} \\
(0.112)\end{array}$ & & & $\begin{array}{l}2.216^{\text {** }} \\
(0.110)\end{array}$ & $\begin{array}{l}1.620^{* *} \\
(0.114)\end{array}$ & $\begin{array}{l}1.252^{* *} \\
(0.119)\end{array}$ \\
\hline Kindergarten Slope & $\begin{array}{l}1.865^{* *} \\
(0.018)\end{array}$ & $\begin{array}{l}1.863^{* *} \\
(0.018)\end{array}$ & $\begin{array}{c}1.866^{* *} \\
(0.018)\end{array}$ & $\begin{array}{c}1.863^{* *} \\
(0.018)\end{array}$ & $\begin{array}{c}1.865^{* *} \\
(0.018)\end{array}$ & $\begin{array}{c}1.866^{* *} \\
(0.018)\end{array}$ & $\begin{array}{l}1.867^{* *} \\
(0.018)\end{array}$ & $\begin{array}{c}1.868^{* *} \\
(0.018)\end{array}$ \\
\hline Black & & & & $\begin{array}{l}-0.237^{* *} \\
(0.045)\end{array}$ & $\begin{array}{l}-0.189 * * \\
(0.045)\end{array}$ & $\begin{array}{l}-0.195^{* *} \\
(0.046)\end{array}$ & $\begin{array}{l}-0.173^{* *} \\
(0.046)\end{array}$ & $\begin{array}{l}-0.155^{* *} \\
(0.047)\end{array}$ \\
\hline Hispanic & & & & $\begin{array}{l}-0.107^{* *} \\
(0.039)\end{array}$ & $\begin{array}{l}-0.049 \\
(0.039)\end{array}$ & $\begin{array}{l}-0.051 \\
(0.039)\end{array}$ & $\begin{array}{l}-0.025 \\
(0.039)\end{array}$ & $\begin{array}{l}-0.028 \\
(0.041)\end{array}$ \\
\hline Asian & & & & $\begin{array}{c}0.115^{*} \\
(0.054)\end{array}$ & $\begin{array}{c}0.121^{*} \\
(0.053)\end{array}$ & $\begin{array}{l}0.184^{* *} \\
(0.055)\end{array}$ & $\begin{array}{l}0.159^{* *} \\
(0.055)\end{array}$ & $\begin{array}{c}0.146^{*} \\
(0.059)\end{array}$ \\
\hline Other race & & & & $\begin{array}{l}-0.071 \\
(0.056)\end{array}$ & $\begin{array}{l}-0.044 \\
(0.056)\end{array}$ & $\begin{array}{l}-0.043 \\
(0.056)\end{array}$ & $\begin{array}{l}-0.033 \\
(0.056)\end{array}$ & $\begin{array}{l}-0.023 \\
(0.056)\end{array}$ \\
\hline SES & & $\begin{array}{c}0.138^{* *} \\
(0.014)\end{array}$ & $\begin{array}{c}0.119 * * \\
(0.014)\end{array}$ & & & $\begin{array}{c}0.128^{* *} \\
(0.014)\end{array}$ & $\begin{array}{l}0.111^{* *} \\
(0.014)\end{array}$ & $\begin{array}{l}0.095^{* *} \\
(0.015)\end{array}$ \\
\hline Concerted cultivation & $\begin{array}{l}0.091^{* *} \\
(0.013)\end{array}$ & & $\begin{array}{l}0.052^{* *} \\
(0.014)\end{array}$ & & & $\begin{array}{l}0.089 * * \\
(0.014)\end{array}$ & $\begin{array}{l}0.055^{* *} \\
(0.015)\end{array}$ & $\begin{array}{c}(0.030)^{*} \\
0.015\end{array}$ \\
\hline Summer Slope & $\begin{array}{l}-0.180^{* *} \\
(0.056)\end{array}$ & $\begin{array}{l}-0.180^{* *} \\
(0.056)\end{array}$ & $\begin{array}{l}-0.180^{* *} \\
(0.056)\end{array}$ & $\begin{array}{l}-0.180^{* *} \\
(0.056)\end{array}$ & $\begin{array}{l}-0.179 * * \\
(0.056)\end{array}$ & $\begin{array}{l}-0.179 * * \\
(0.056)\end{array}$ & $\begin{array}{l}-0.179 * * \\
(0.056)\end{array}$ & $\begin{array}{l}-0.180^{* *} \\
(0.056)\end{array}$ \\
\hline Black & & & & $\begin{array}{c}0.199 \\
(0.175)\end{array}$ & $\begin{array}{c}0.274 \\
(0.176)\end{array}$ & $\begin{array}{c}0.267 \\
(0.176)\end{array}$ & $\begin{array}{c}0.305 \\
(0.177)\end{array}$ & $\begin{array}{c}0.285 \\
(0.180)\end{array}$ \\
\hline Hispanic & & & & $\begin{array}{c}0.166 \\
(0.159)\end{array}$ & $\begin{array}{c}0.242 \\
(0.159)\end{array}$ & $\begin{array}{c}0.236 \\
(0.161)\end{array}$ & $\begin{array}{c}0.270 \\
(0.161)\end{array}$ & $\begin{array}{c}0.292 \\
(0.166)\end{array}$ \\
\hline Asian & & & & $\begin{array}{l}0.721^{* *} \\
(0.224)\end{array}$ & $\begin{array}{l}0.720^{* *} \\
(0.223)\end{array}$ & $\begin{array}{l}0.825^{* *} \\
(0.227)\end{array}$ & $\begin{array}{l}0.792 \text { ** } \\
(0.227)\end{array}$ & $\begin{array}{l}0.797^{* *} \\
(0.241)\end{array}$ \\
\hline Other race & & & & $\begin{array}{c}0.333 \\
(0.212)\end{array}$ & $\begin{array}{c}0.382 \\
(0.211)\end{array}$ & $\begin{array}{c}0.374 \\
(0.213)\end{array}$ & $\begin{array}{c}0.388 \\
(0.213)\end{array}$ & $\begin{array}{c}0.373 \\
(0.214)\end{array}$ \\
\hline SES & & $\begin{array}{l}0.200^{* *} \\
(0.055)\end{array}$ & $\begin{array}{l}0.191^{* *} \\
(0.058)\end{array}$ & & & $\begin{array}{l}0.213^{* *} \\
(0.056)\end{array}$ & $\begin{array}{l}0.187^{* *} \\
(0.058)\end{array}$ & $\begin{array}{l}0.194^{* *} \\
(0.060)\end{array}$ \\
\hline Concerted cultivation & $\begin{array}{c}0.086 \\
(0.053)\end{array}$ & & $\begin{array}{c}0.026 \\
(0.056)\end{array}$ & & & $\begin{array}{c}0.130^{*} \\
(0.055)\end{array}$ & $\begin{array}{c}0.072 \\
(0.057)\end{array}$ & $\begin{array}{c}0.041 \\
(0.060)\end{array}$ \\
\hline First-Grade Slope & $\begin{array}{l}3.366^{* *} \\
(0.029)\end{array}$ & $\begin{array}{l}3.364^{* *} \\
(0.029)\end{array}$ & $\begin{array}{c}3.367^{* *} \\
(0.029)\end{array}$ & $\begin{array}{c}3.363^{* *} \\
(0.029)\end{array}$ & $\begin{array}{l}3.365^{* *} \\
(0.029)\end{array}$ & $\begin{array}{c}3.366^{* *} \\
(0.029)\end{array}$ & $\begin{array}{l}3.367^{* *} \\
(0.029)\end{array}$ & $\begin{array}{c}3.368^{* *} \\
(0.029)\end{array}$ \\
\hline Black & & & & $\begin{array}{l}-0.263^{* *} \\
(0.074)\end{array}$ & $\begin{array}{l}-0.209 * * \\
(0.074)\end{array}$ & $\begin{array}{l}-0.198^{* *} \\
(0.074)\end{array}$ & $\begin{array}{l}-0.177^{*} \\
(0.074)\end{array}$ & $\begin{array}{l}-0.167^{*} \\
(0.075)\end{array}$ \\
\hline
\end{tabular}


Table 4. Continued.

\begin{tabular}{|c|c|c|c|c|c|c|c|c|}
\hline \multirow[b]{2}{*}{ Variables $^{\mathrm{a}}$} & \multicolumn{8}{|c|}{ Model } \\
\hline & $\mathrm{A}$ & B & $\mathrm{C}$ & $\mathrm{D}$ & $\mathrm{E}$ & $\mathrm{F}$ & G & $\mathrm{H}$ \\
\hline Hispanic & & & & $\begin{array}{l}-0.200 * * \\
(0.065)\end{array}$ & $\begin{array}{l}-0.128 * \\
(0.064)\end{array}$ & $\begin{array}{l}-0.117 \\
(0.065)\end{array}$ & $\begin{array}{l}-0.088 \\
(0.065)\end{array}$ & $\begin{array}{l}-0.108 \\
(0.067)\end{array}$ \\
\hline Asian & & & & $\begin{array}{l}-0.055 \\
(0.090)\end{array}$ & $\begin{array}{l}-0.043 \\
(0.089)\end{array}$ & $\begin{array}{c}0.046 \\
(0.091)\end{array}$ & $\begin{array}{c}0.016 \\
(0.091)\end{array}$ & $\begin{array}{l}-0.013 \\
(0.096)\end{array}$ \\
\hline Other race & & & & $\begin{array}{l}-0.061 \\
(0.090)\end{array}$ & $\begin{array}{l}-0.031 \\
(0.090)\end{array}$ & $\begin{array}{l}-0.021 \\
(0.090)\end{array}$ & $\begin{array}{l}-0.006 \\
(0.090)\end{array}$ & $\begin{array}{c}0.004 \\
(0.090)\end{array}$ \\
\hline SES & & & & $\begin{array}{l}0.161^{* *} \\
(0.023)\end{array}$ & $\begin{array}{l}0.126^{* *} \\
(0.024)\end{array}$ & $\begin{array}{l}0.152^{* *} \\
(0.023)\end{array}$ & $\begin{array}{l}0.119^{* *} \\
(0.024)\end{array}$ & $\begin{array}{l}0.092^{* *} \\
(0.025)\end{array}$ \\
\hline Concerted cultivation & $\begin{array}{c}0.144^{* *} \\
(0.022)\end{array}$ & & $\begin{array}{c}0.102 * * \\
(0.023)\end{array}$ & & & $\begin{array}{c}0.136^{* *} \\
(0.023)\end{array}$ & $\begin{array}{c}0.098^{* *} \\
(0.024)\end{array}$ & $\begin{array}{c}0.072^{* *} \\
(0.024)\end{array}$ \\
\hline \multicolumn{9}{|l|}{ Second-to Third-Grade } \\
\hline Slope & $\begin{array}{c}1.578^{* *} \\
(0.009)\end{array}$ & $\begin{array}{c}1.578 * * \\
(0.009)\end{array}$ & $\begin{array}{l}1.578^{* *} \\
(0.009)\end{array}$ & $\begin{array}{l}1.577 \text { ** } \\
(0.009)\end{array}$ & $\begin{array}{c}1.578 * * \\
(0.009)\end{array}$ & $\begin{array}{l}1.577^{* *} \\
(0.009)\end{array}$ & $\begin{array}{l}1.577^{* *} \\
(0.009)\end{array}$ & $\begin{array}{l}1.577^{* *} \\
(0.009)\end{array}$ \\
\hline Black & & & & $\begin{array}{l}-0.115^{* *} \\
(0.027)\end{array}$ & $\begin{array}{l}-0.109 * * \\
(0.026)\end{array}$ & $\begin{array}{l}-0.110^{* *} \\
(0.027)\end{array}$ & $\begin{array}{l}-0.111^{* *} \\
(0.027)\end{array}$ & $\begin{array}{l}-0.118^{* *} \\
(0.027)\end{array}$ \\
\hline Hispanic & & & & $\begin{array}{l}-0.016 \\
(0.022)\end{array}$ & $\begin{array}{l}-0.015 \\
(0.022)\end{array}$ & $\begin{array}{l}-0.011 \\
(0.023)\end{array}$ & $\begin{array}{l}-0.011 \\
(0.023)\end{array}$ & $\begin{array}{l}-0.015 \\
(0.024)\end{array}$ \\
\hline Asian & & & & $\begin{array}{l}-0.206^{* *} \\
(0.030)\end{array}$ & $\begin{array}{l}-0.202^{* *} \\
(0.030)\end{array}$ & $\begin{array}{l}-0.200^{* *} \\
(0.031)\end{array}$ & $\begin{array}{l}-0.198^{* *} \\
(0.031)\end{array}$ & $\begin{array}{l}-0.203^{* *} \\
(0.033)\end{array}$ \\
\hline Other race & & & & $\begin{array}{l}-0.076^{*} \\
(0.033)\end{array}$ & $\begin{array}{l}-0.082^{*} \\
(0.033)\end{array}$ & $\begin{array}{l}-0.075^{*} \\
(0.033)\end{array}$ & $\begin{array}{l}-0.076^{*} \\
(0.033)\end{array}$ & $\begin{array}{l}-0.077^{*} \\
(0.033)\end{array}$ \\
\hline SES & & & & $\begin{array}{c}0.000 \\
(0.008)\end{array}$ & $\begin{array}{l}-0.007 \\
(0.008)\end{array}$ & $\begin{array}{l}-0.002 \\
(0.008)\end{array}$ & $\begin{array}{l}-0.004 \\
(0.008)\end{array}$ & $\begin{array}{l}-0.015 \\
(0.009)\end{array}$ \\
\hline Concerted cultivation & $\begin{array}{c}0.019 * \\
(0.008)\end{array}$ & & $\begin{array}{c}0.021^{*} \\
(0.008)\end{array}$ & & & $\begin{array}{c}0.008 \\
(0.008)\end{array}$ & $\begin{array}{c}0.010 \\
(0.008)\end{array}$ & $\begin{array}{c}0.001 \\
(0.009)\end{array}$ \\
\hline
\end{tabular}

${ }^{*} p<.05,{ }^{* *} p<.01$.

Note: Standard errors are in parentheses.

a The results and the full covariate list for Model G are displayed in Table 5.

ity to nonsignificance and suggesting that the early childhood black-white reading gap results from different patterns of parental educational investment, a reduction of 72 percent above and beyond parental SES (Model E versus Model G).

The black-white disparity grows during the school year across model specifications. From kindergarten to the first grade, concerted cultivation mediates approximately 20 percent to 25 percent of the gap, similar to that explained by socioeconomic background, while the additional family context variables explain an additional 20 percent and 16 percent, respectively, although none of the covariates included in Model $\mathrm{H}$ is implicated in the growth in the achievement gap during the second and third grades. Notably, there is no indication of differential growth in the summer.
Hispanic-White Gap The within-school Hispanic-white gap is larger than that reported for blacks and whites, being nearly 3 points or $.35 S D$ (relative to the within-school, between-child $S D$ ). In Model E, socioeconomic background mediates approximately 32 percent of the gap, while concerted cultivation mediates an additional 32 percent (Model E versus Model G). Entering the family context variables (Model $\mathrm{H}$ ) further mediates the achievement disadvantage at kindergarten entry, reducing the difference to 1.1 points, although the coefficient remains statistically significant across specifications. Hispanic children grow more slowly over kindergarten and the first grade (Model D), although the slower growth is reduced to nonsignificance when concerted cultivation is adjusted for. 
Asian-White Gap Asian children have more than a 1-point advantage (Model D) at kindergarten entry. In a fashion similar to the math results, the Asian-white gap increases to over 2.7 points in magnitude in Model F, again indicating that concerted cultivation cannot explain the Asian advantage and that Asian children who come from homes with the same level of concerted cultivation as white children, on average, have higher levels of reading performance. Furthermore, the other family covariates that are included in Model $\mathrm{H}$ do not explain this advantage.

Asian children grow more quickly over the kindergarten year and the summer across model specifications. The kindergarten growth advantage increases from .12 to .18 points when concerted cultivation is added to the model, and adding the full covariate does not explain this advantage. In addition, while children on average lose .18 points of ground per month over the summer, Asian children gain nearly $(.721-.180 \approx) .55$ points per month, which provides a large bump in Asian children's scores relative to those of children from other groups. The Asian advantage, however, deteriorates rapidly over the second- to third-grade period, and the family covariates contribute little to our understanding of Asian children's slower growth over this period.

Family Context In addition to the covariates discussed so far, results for the full covariate list (Model H) are presented in Table 5. Girls enter kindergarten with a 1-point advantage over boys, while children from homes where a non-English language is spoken score approximately 1.6 points lower than their English-only schoolmates - a deficit approximately equal to $1 S D$ of socioeconomic background. Children from stepparent families also have less favorable scores, although children in single-parent families do not enter kindergarten statistically differentiable, while children from families with less favorable child-adult ratios have lower reading achievement. Neither maternal age nor part-time employment are related to children's initial status, although children whose mothers do not work report higher average scores relative to those whose mothers are employed full time. Although children whose parents have lower educational expectations do not enter school with skill differentials compared to children from families whose parents expect them to obtain some college education, children with highly expectant parents enter school with a .8-point advantage. Relative to children who received no prekindergarten care, those who received home-based care entered kindergarten with higher scores, while those who attended centerbased care had more than a 1.6-point advantage.

\section{Decomposing Socioeconomic Background}

In this next model series, presented in Appendix Table A- 1 , the differential mediation of concerted cultivation on the components of socioeconomic background for math and reading are assessed at kindergarten entry using school fixed-effects models. Parental education has by far the largest association with children's math and reading scores at kindergarten entry, far larger than either parental occupational prestige or income (column A1). Adjusting for concerted cultivation reduces the occupational prestige coefficient by approximately 10 percent, the parental education gradient by more than 20 percent, and the income association by approximately 30 percent, for both math and reading. These results indicate that the socioeconomic difference in children's test scores is driven most strongly by parental education and that while more than 20 percent of this association is mediated by concerted cultivation, the measure of educational investment explains more than 30 percent of the income effect, suggesting that concerted cultivation is implicated in both the economic and cultural components of socioeconomic background, but that the measure, as used here, is more strongly related to income or resource effects on children's learning, perhaps because books are included in the measure.

\section{Discussion}

Recent longitudinal studies using the ECLS-K have provided important insights into changes in math and reading disparities after children enter kindergarten (Downey et al. 2004; Reardon 2003). 
Table 5. Parameter Estimates for Model H from Table 4

\begin{tabular}{|c|c|c|c|c|c|}
\hline Coefficients & $\begin{array}{l}\text { Initial } \\
\text { Status }\end{array}$ & $\begin{array}{l}\text { Kindergarten } \\
\text { Slope }\end{array}$ & $\begin{array}{l}\text { Summer } \\
\text { Slope }\end{array}$ & $\begin{array}{l}\text { 1st-Grade } \\
\text { Slope }\end{array}$ & $\begin{array}{l}\text { 2nd- to 3rd- } \\
\text { Grade Slope }\end{array}$ \\
\hline Intercept & $\begin{array}{l}23.220^{* *} \\
(0.162)\end{array}$ & $\begin{array}{l}1.868^{* *} \\
(0.018)\end{array}$ & $\begin{array}{l}-0.180^{* *} \\
(0.056)\end{array}$ & $\begin{array}{l}3.368^{* *} \\
(0.029)\end{array}$ & $\begin{array}{l}1.577^{* *} \\
(0.009)\end{array}$ \\
\hline Black & $\begin{array}{l}-0.169 \\
(0.373)\end{array}$ & $\begin{array}{l}-0.155^{* *} \\
(0.047)\end{array}$ & $\begin{array}{c}0.285 \\
(0.180)\end{array}$ & $\begin{array}{l}-0.167^{*} \\
(0.075)\end{array}$ & $\begin{array}{l}-0.118^{* *} \\
(0.027)\end{array}$ \\
\hline Hispanic & $\begin{array}{l}-1.113^{* *} \\
(0.316)\end{array}$ & $\begin{array}{l}-0.028 \\
(0.041)\end{array}$ & $\begin{array}{c}0.292 \\
(0.166)\end{array}$ & $\begin{array}{l}-0.108 \\
(0.067)\end{array}$ & $\begin{array}{l}-0.015 \\
(0.024)\end{array}$ \\
\hline Asian & $\begin{array}{l}2.625^{* *} \\
(0.458)\end{array}$ & $\begin{array}{r}0.146^{*} \\
(0.059)\end{array}$ & $\begin{array}{l}0.797^{* * *} \\
(0.241)\end{array}$ & $\begin{array}{l}-0.013 \\
(0.096)\end{array}$ & $\begin{array}{l}-0.203^{* *} \\
(0.033)\end{array}$ \\
\hline Other & $\begin{array}{c}0.091 \\
(0.432)\end{array}$ & $\begin{array}{l}-0.023 \\
(0.056)\end{array}$ & $\begin{array}{c}0.373 \\
(0.214)\end{array}$ & $\begin{array}{c}0.004 \\
(0.090)\end{array}$ & $\begin{array}{l}-0.077^{*} \\
(0.033)\end{array}$ \\
\hline Socioeconomic status & $\begin{array}{l}1.626^{* *} \\
(0.116)\end{array}$ & $\begin{array}{l}0.095^{* *} \\
(0.015)\end{array}$ & $\begin{array}{l}0.194^{* *} \\
(0.060)\end{array}$ & $\begin{array}{l}0.092^{* *} \\
(0.025)\end{array}$ & $\begin{array}{l}-0.015 \\
(0.009)\end{array}$ \\
\hline Concerted cultivation & $\begin{array}{l}1.252^{* *} \\
(0.119)\end{array}$ & $\begin{array}{c}0.030^{*} \\
(0.015)\end{array}$ & $\begin{array}{c}0.041 \\
(0.060)\end{array}$ & $\begin{array}{l}0.072^{* *} \\
(0.024)\end{array}$ & $\begin{array}{c}0.001 \\
(0.009)\end{array}$ \\
\hline Age at kindergarten entry & $\begin{array}{l}0.319^{* *} \\
(0.020)\end{array}$ & & & & \\
\hline Female & $\begin{array}{l}1.039^{* *} \\
(0.165)\end{array}$ & $\begin{array}{l}0.106^{* *} \\
(0.021)\end{array}$ & $\begin{array}{c}0.146 \\
(0.085)\end{array}$ & $\begin{array}{c}0.059 \\
(0.035)\end{array}$ & $\begin{array}{l}-0.003 \\
(0.012)\end{array}$ \\
\hline Second-time kindergartner & $\begin{array}{l}2.015^{* *} \\
(0.440)\end{array}$ & $\begin{array}{l}-0.275^{* *} \\
(0.058)\end{array}$ & $\begin{array}{l}-0.126 \\
(0.234)\end{array}$ & $\begin{array}{l}-0.423^{* *} \\
(0.091)\end{array}$ & $\begin{array}{l}-0.047 \\
(0.034)\end{array}$ \\
\hline Non-English language at home & $\begin{array}{l}-1.563^{* *} \\
(0.369)\end{array}$ & $\begin{array}{l}-0.008 \\
(0.048)\end{array}$ & $\begin{array}{l}-0.160 \\
(0.189)\end{array}$ & $\begin{array}{c}0.003 \\
(0.074)\end{array}$ & $\begin{array}{l}-0.017 \\
(0.026)\end{array}$ \\
\hline Stepparent & $\begin{array}{l}-0.699^{*} \\
(0.329)\end{array}$ & $\begin{array}{l}-0.042 \\
(0.041)\end{array}$ & $\begin{array}{l}-0.146 \\
(0.152)\end{array}$ & $\begin{array}{l}-0.030 \\
(0.058)\end{array}$ & $\begin{array}{l}0.061^{* *} \\
(0.020)\end{array}$ \\
\hline Single parent & $\begin{array}{l}-0.048 \\
(0.243)\end{array}$ & $\begin{array}{l}-0.069^{*} \\
(0.031)\end{array}$ & $\begin{array}{c}0.099 \\
(0.113)\end{array}$ & $\begin{array}{l}-0.056 \\
(0.044)\end{array}$ & $\begin{array}{c}0.024 \\
(0.017)\end{array}$ \\
\hline Other family structure & $\begin{array}{l}-0.907 \\
(0.474)\end{array}$ & $\begin{array}{l}-0.144^{*} \\
(0.060)\end{array}$ & $\begin{array}{c}0.084 \\
(0.215)\end{array}$ & $\begin{array}{l}-0.159 \\
(0.090)\end{array}$ & $\begin{array}{c}0.056 \\
(0.033)\end{array}$ \\
\hline Child/adult ratio- 1 & $\begin{array}{l}-0.964^{* *} \\
(0.113)\end{array}$ & $\begin{array}{l}-0.034^{*} \\
(0.014)\end{array}$ & $\begin{array}{l}-0.091 \\
(0.052)\end{array}$ & $\begin{array}{l}-0.008 \\
(0.021)\end{array}$ & $\begin{array}{l}-0.018^{*} \\
(0.008)\end{array}$ \\
\hline Mother's age (centered) & $\begin{array}{c}0.027 \\
(0.015)\end{array}$ & $\begin{array}{c}0.002 \\
(0.002)\end{array}$ & $\begin{array}{l}-0.003 \\
(0.007)\end{array}$ & $\begin{array}{l}-0.001 \\
(0.003)\end{array}$ & $\begin{array}{c}0.002 \\
(0.001)\end{array}$ \\
\hline Mother works part time & $\begin{array}{c}0.327 \\
(0.230)\end{array}$ & $\begin{array}{c}0.042 \\
(0.028)\end{array}$ & $\begin{array}{c}0.077 \\
(0.091)\end{array}$ & $\begin{array}{l}-0.020 \\
(0.033)\end{array}$ & $\begin{array}{c}0.024 \\
(0.014)\end{array}$ \\
\hline Mother does not work & $\begin{array}{l}0.779 * * \\
(0.236)\end{array}$ & -0.020 & 0.132 & -0.038 & 0.004 \\
\hline $\begin{array}{l}\text { Mother worked before } \\
\text { child's birth }\end{array}$ & $\begin{array}{c}0.157 \\
(0.209)\end{array}$ & $(0.025)$ & $(0.086)$ & $(0.034)$ & $(0.016)$ \\
\hline $\begin{array}{l}\text { High school or less } \\
\text { educational expectations }\end{array}$ & $\begin{array}{l}-0.604 \\
(0.310)\end{array}$ & $\begin{array}{l}-0.144^{* *} \\
(0.040)\end{array}$ & $\begin{array}{l}-0.039 \\
(0.125)\end{array}$ & $\begin{array}{l}-0.406^{* *} \\
(0.044)\end{array}$ & $\begin{array}{l}-0.175^{* *} \\
(0.019)\end{array}$ \\
\hline $\begin{array}{l}\text { Graduate school educational } \\
\text { expectations }\end{array}$ & $\begin{array}{l}0.806^{* *} \\
(0.194)\end{array}$ & $\begin{array}{c}0.003 \\
(0.025)\end{array}$ & $\begin{array}{c}0.064 \\
(0.081)\end{array}$ & $\begin{array}{c}0.036 \\
(0.034)\end{array}$ & $\begin{array}{r}0.043^{*} \\
(0.014)\end{array}$ \\
\hline Home-based care & $\begin{array}{r}0.638^{*} \\
(0.256)\end{array}$ & & & & \\
\hline Head Start & $\begin{array}{c}0.101 \\
(0.347)\end{array}$ & & & & \\
\hline Center-based care & $\begin{array}{l}1.639^{* *} \\
(0.239)\end{array}$ & & & & \\
\hline Changed schools & & $\begin{array}{l}-0.099 \\
(0.090)\end{array}$ & $\begin{array}{l}-0.001 \\
(0.136)\end{array}$ & $\begin{array}{l}-0.298^{*} \\
(0.115)\end{array}$ & $\begin{array}{l}-0.037^{*} \\
(0.016)\end{array}$ \\
\hline Variance Components & & & & & \\
\hline $\begin{array}{l}\text { Level } 2 \\
\text { Level } 3\end{array}$ & $\begin{array}{l}62.692^{* *} \\
18.268^{* *}\end{array}$ & $\begin{array}{l}0.846^{* *} \\
0.193^{* *}\end{array}$ & $\begin{array}{l}3.336^{* *} \\
0.497^{* *}\end{array}$ & $\begin{array}{l}1.800^{* *} \\
0.430^{* *}\end{array}$ & $\begin{array}{l}0.351^{* *} \\
0.043^{* *}\end{array}$ \\
\hline
\end{tabular}

${ }^{*} p<.05,{ }^{* *} p<.01$. 
The descriptive components of this study are relatively consistent with these previous reports, and along with Downey et al. (2004), I found that although between-child measures are related to children's learning, the impact on growth is modest relative to the total amount of growth that children experience while in school. This analysis has gone beyond these initial descriptive studies by adding another wave of data and elaborating the between-child components of the model with indicators of the family context to gain a better understanding of the transition to school (Entwisle and Alexander 1989, 1993) and to address the role of the family in children's learning after entering school and during the summer (Alexander et al. 2001; Cooper et al. 1996; Entwisle and Alexander 1992). Particular attention was given to the role of a measure of parent educational investments as defined by Lareau (2002, 2003). Past researchers have dedicated considerable energy to operationalizing parental educational and cultural investments in empirical analyses of children's grades and achievement, resulting in a variety of operationalizations (Aschaffenberg and Maas 1997; De Graaf, De Graaf, and Kraaykamp 2000; DiMaggio 1982; Dumais 2002; Farkas 2003; Farkas et al. 1990; Teachman 1997).

This analysis was organized around Lareau's (2003) ethnography, which suggests that a composite measure of parenting that is based on three dimensions of educational investment, child participation in adult-orchestrated leisure activities, investment in educational materials, and involvement with the school should do the following:

1. Be related to children's skill levels at kindergarten entry. The coefficient magnitudes for math and reading were relatively large, approximately 80 percent of the socioeconomic gradients when both were in the model, indicating that concerted cultivation is related to important early academic advantages.

2. Be related to children's educational development after school entry. Concerted cultivation was related to children's math growth after school entry, with positive impacts on growth over the summer and kindergarten year, although the measure was not consistently related to later school-year growth. While concerted cultivation was not related to children's growth in reading during the summer, it was associated with greater learning during kindergarten and the first grade. These results indicate that early in their educational careers, children recoup modest returns to the concerted-cultivation pattern of educational investment, although the returns appear to decrease as children age.

3. Play a significant role in explaining socioeconomic gaps in children's learning. Mediation of the parameters of growth by socioeconomic background was typically about 20 percent, indicating a modest implication for concerted cultivation in socioeconomic advantage. These results suggest that concerted cultivation is only a partial explanation for socioeconomic educational advantages.

4. Not be significantly associated with racial/ethnic differences in children's learning after socioeconomic background is adjusted for. Concerted cultivation was strongly related to black-white and Hispanic-white gaps net of SES, reducing the black-white reading gap at kindergarten entry to nonsignificance. Black and Hispanic children came from families, net of socioeconomic background, that practiced lower levels of concerted cultivation and entered school with lower test scores as a result. Once the children entered school, however, the role of concerted cultivation in achievement disparities became less clear. Asian children who came from concerted-cultivating families performed better than did their white counterparts, suggesting that this pattern of educational investment is not implicated in Asian school success. These results indicate that net of socioeconomic background, nonwhite parents were less likely to endorse concerted cultivation and that this differential pattern of educational investment, for black and Hispanic children, was related to academic disparities when children entered school and growth in the Hispanic-white gap after school entry.

Overall, the results only partially support Lareau (2002, 2003). As I noted earlier, concerted cultivation is related to children's academic skills at kindergarten entry and growth early in their academic careers. As a mediator of socioeconomic 
background, however, these results indicate that while concerted cultivation plays a role in explaining socioeconomic advantage, it is only a modest part of the story. In addition, the measure of the concerted-cultivation pattern of parental educational investments explained more of the income than educational association with children's skills at kindergarten entry, which supports the contention that Lareau (2003) overemphasized the role of culture in parental investments (Chin and Phillips 2004).

With regard to the role of concerted cultivation in racial/ethnic disadvantage, the findings directly contradict Lareau's (2002) argument that net of social class or socioeconomic background, concerted cultivation and race are unrelated, which implies that concerted cultivation cannot explain racial/ethnic gaps in children's academic skills. In contrast, even after I controlled for socioeconomic background, the concerted-cultivation pattern of educational investment was related to racial/ethnic disparities in skills, reducing the black-white reading gap at kindergarten entry to nonsignificance, mediating a large proportion of the Hispanic-white gap at kindergarten entry, and largely accounting for growth in the Hispanic-white gap over the study period.

Socioeconomic background is only partly captured by the measure that I used, since wealth was not included in the creation of the SES variable (e.g., Conley 1999; the measure used was comprised of education, income, and occupation). If wealth is more strongly related to parental endorsement of concerted cultivation than to the components included in the measure and is also related to early children's learning, then the role of concerted cultivation in explaining socioeconomic advantage is understated. In addition, because there are important racial/ethnic disparities in wealth (Conley 1999; Shapiro 2004), not accounting for wealth could partly explain the residual importance of concerted cultivation in racial/ethnic learning gaps. However, despite the importance of wealth for later outcomes (Conley 1999; Shapiro 2004), the pathways through which wealth influences early development are less clear. Although it is pos- sible that assets allow families to provide larger and more consistent housing, obtain lower mortgages and hence to have more disposable income, and save more for their children's college education (Rothstein 2004), previous research has failed to find a strong link between assets and wealth and children's achievement (Phillips et al. 1998) or debt and school performance (Hanson, McLanahan, and Thomson 1997). However, if wealth is used to create extra disposable income and/or purchase residences with access to high-quality extramural activities for children, then only a limited part of the relationship among SES, concerted cultivation, racial/ethnic background, and educational inequality has been captured here.

Despite the success of the concerted-cultivation measure in explaining growth in the gap in Hispanic-white achievement after children enter school, growth in the black-white gap remains distressingly resilient. Neither socioeconomic background nor parents' educational investments, family structure, the child-adult ratio, maternal age, maternal employment, or parents' educational expectations is able to account for the growth in the black-white achievement disparity between children who attend the same schools (see also Phillips, Crouse, and Ralph 1998). Since differential growth occurs during the school year when family variables have little impact on growth, these results suggest that within-school processes or school-level confounders that interact with race are the principal sources of the growing gap in achievement after school entry. There are a number of possible reasons for the within-school growth in this gap (Downey et al. 2004; Entwisle and Alexander 1994; Farkas 1996; Phillips, Crouse, and Ralph 1998; Rothstein 2004), such as differential treatment by teachers, differences in noncognitive behaviors related to learning, linguistic mismatch, and discrimination, but the only certain thing, other than the growth in the gap itself, is that this troubling pattern suggests the need for stronger within-school, classroombased research designs.

Despite the broad developmental implications of the concerted-cultivation pattern of investment, the measure was not implicated in Asian children's 
skill advantage, and Asian children who experienced levels comparable to white children's tended to score higher. Notably, adding the family context variables had little additional impact on the Asian coefficients or accounted for the suppressor relationship between the Asian and concertedcultivation coefficients. These analyses provide little insight into the sources of the Asian advantage, strongly suggesting that other factors than those included here need to be assessed. The frequent better performance of Asian children than of white children from families with the same levels of concerted cultivation and the extreme magnitude of Asian children's summer advantage suggest different patterns of parental investment than those used by other parents (Sun 1998; see also Zhou and Bankston 1998). Sun, for example, argued that Asian parents tend to focus on only the most beneficial, within-family components of investment. Given the imperviousness of the Asian-white differences across model specifications, the reasons for Asian children's advantages remain an important area of research, implying that no single model of educational achievement adequately captures the racial-ethnic heterogeneity of the United States (Kao and Thompson 2003).

The family environment, in general, was not strongly related to children's achievement after school entry. Its role and that of behavioral patterns like concerted cultivation in academic developmental processes may decline over time as the nature of the materials changes. Math, for example, becomes increasingly complex after the basic mechanics are learned. With regard to reading, Chall (1996a, 1996b; see also Chall, Jacobs, and Baldwin 1990; Honig 1996), for example, noted that reading proceeds in stages. Children, as the saying goes, learn to read during the kindergarten year, solidify these skills over the second and third grades, and begin reading to learn later (Snow, Burns, and Griffin 1998), suggesting that after a lull in importance after the first grade, when reading mechanics solidify, parenting and family characteristics may reemerge as children's vocabularies and knowledge about the world become more important.
Of course, this study was limited in a number of important ways. The misfit with Lareau's expectations may have been the result of inadequacies in the model or the covariates used to identify the latent variable. The use of reasoning and directives in parent-child interactions was notably absent from this model and is an important design issue of relevance to future projects that link parenting to educational achievement. If such measures were available, the mediation of socioeconomic gradients may have been larger, although the mediation of the racial/ethnic gaps may have increased as well. However, the latent variable measure is identified by the relationships among the indicators of concerted cultivation, and these correlations are considerable, so to the extent that linguistic patterns are also tied to children's participation in activities, parental participation with school, and children's reading materials, then at least some of the linguistic components of parent-child relationships were captured with the measure that was used. Yet it is doubtful that the measure was able to capture the full potential impact of the concerted-cultivation pattern of parental investment or that the design that relied on using books to anchor part of the measure could fully resolve whether the practice of concerted cultivation is cultural or economic (e.g., Chin and Phillips 2004). In addition, a continuous measure of concerted cultivation was operationalized, and the literature would be well served by a fuller test of Lareau's hypotheses comparing continuous to categorical operationalizations using latent class analysis or mixture models to identify fully children who grow up experiencing "the accomplishment of natural growth."

\section{Conclusion}

What does the measure of concerted cultivation really capture about children's lives? The concertedcultivation regression coefficients presented here capture packages of effects that probably cannot be isolated without recourse to either experimentation or a small class of high-quality quasi-experiments. The measure of parental educational investment 
was not composed of the most proximate parental behaviors (e.g., reading behaviors or verbal strategies). It was much more distal, operating from the idea that a broad conception of childhood is related to academic development. Children are systematically exposed to different types of play, while their parents systematically differentially participate with their children's schools and systematically create different learning environments for them. Children from concerted-cultivating families likely enter schools relatively advantaged because their parents are generally proactive about their education, and education is broadly construed to reflect the development of both their cognitive and noncognitive skills, of which the focus on reading and mathematics here is only a small part.

The results highlight that the gestalt of children's early experiences is related to academic development, although the differences in parenting that were used in this study by no means tell the entire story or overwhelmingly conform to Lareau's (2003) expectations. The measures did not ask whether enrollment in specific activities or types of parental involvement with school predict achievement. Certainly, specific indicators may be important, but the latent variable that was used suggests that the underlying propensities for parents to be involved, to involve their children, and to acquire reading materials for them are important predictors of the development of academic skills. The correspondence of these behaviors anchors the meaning of the concerted-cultivation variable to the general, rather than specific, although it is impossible with this strategy to separate the parenting effect from the child-experiences effect. Concerted cultivation matters because the style of parenting investments values children's cognitive environments, because concerted-cultivating parents spend a good deal of time talking with their children while shuffling them to different activities, and because parents network and acquire information at children's events and when they are involved with their children's schools (Horvat, Weininger, and Lareau 2003). Concerted cultivation also matters because children learn to be self-confident on the soccer field, interact with other adults there, and have the educational resources to self-select engaging materials (e.g., Guo and Stearns 2002).

It is precisely the fact that parenting styles and children's experiences both matter that studies that paint parenting in broad strokes are difficult to generalize toward clear-cut policy recommendations. One would not expect the return to disadvantaged children's reading scores from a book-distribution program to be the same as that reported for this sample, for example, because disadvantaged parents do not approach reading the same way as do advantaged parents (Rothstein 2004). One also would not expect the same return to children's participation in activities to be of the same magnitude through public after-school programs. Not only are these programs likely to be larger and of lower quality, but disadvantaged children are probably not likely to spend their time commuting with their parents, talking with them about their day, and contextualizing their experiences. If parents do not attend these functions, they may also network less effectively with each other to gain information about courses, teachers, and schools (Horvat et al. 2003).

It is in these distinctions that the spirit of this work is most clear, since the measure of concerted cultivation is relatively distal to learning processes. While there are hypothesized links to specific learning strategies, including scaffolding or reading behaviors (e.g., Hart and Risley 1995) and the practice of concerted cultivation, the broad brush of the concerted-cultivation measure that I used is most useful as a generalized statement about how the home lives of children are unequal and that this inequality is translated into educational inequality that is part of larger systemic patterns of inequality that persist across generations (see Phillips, Brooks-Gunn et al. 1998). Concerted cultivation requires knowledge of the underlying cultural logic on which it is based, and parents must have the skills and resources to actuate this logic as an organizing strategy of investment in their children. At the same time, the roles of the larger community and the ways in which community characteristics interact with race/ethnicity need to be better understood in the context of Lareau's model (for 
motivation, see Pattillo-McCoy 1999). To the extent that parents cannot realize their parenting goals or are not familiar with the investment patterns that advantaged parents use to help ensure their children's success, educational and other public institutions will probably always be faced with, and asked to make up for, the complex problems surrounding the social inequality that arises from family life, regardless of the difficulty or the extent to which mediating family disadvantage is feasible.

\section{Notes}

1. Residual correlations in the model among dance lessons, music lessons, and participation in organized performance arts are necessary because of the nonuniqueness of the last category. In addition, allowing these between-item residual correlations improves the model fit.

2. Furthermore, including them has little impact on the estimates of concerted cultivation, since the factor scores across a number of model specifications are nearly perfectly correlated.

3. The natural logarithm $(\ln )$ of the number of books was taken, since it is hard to imagine that an additional book means the same for a child who has 100 compared to 5 books. In addition, large variances in SEM can lead to estimation problems, which was the case here. Taking the In led to more stable estimation. Although it is also possible to include whether there is a computer in the home, including this item contributed only a small amount of additional information and did not lead to significantly different posterior factor-score estimates or alter later conclusions, perhaps because parents have computers for a variety of reasons, while children's books are specifically educational and are tailored more specifically to children's needs.
4. Unless otherwise noted, information for this section is drawn from NCES (2002).

5. Growth during this period is a weighted average of growth over two school years and summers.

6. One anonymous reviewer wondered if modeling the second- to third-grade period was appropriate since it is an admixture of two schooling periods and two summers. This mixing of periods makes it impossible to determine school and out-of-school effects that are specific to each period, but still allowed me to estimate the relationship between the covariates of interest and average growth-estimates that are similar to those found for most previous educational growth models where age or time was the variable of interest but period-specific schooling information was lacking. Indeed, the estimation of periodspecific effects is one of the unique characteristics of the ECLS-K, and the ability to estimate the effects of certain periods should not imply that it is no longer worthwhile to estimate mixed-temporal effects, such as those over the second- to third-grade period estimated here.

7. The wave-specific precision weights are constructed as $1 /\left(1-a_{t}\right) \sigma_{t}^{2}$, where $a_{t}$ is the test reliability at wave $t$, and $\sigma_{t}^{2}$ is the variance of the IRT scale scores at wave $t$.

8. An alternative approach would be simply to include the group means in the Level 3 model, although this approach substantially increases the number of parameters that need to be estimated in an already highly parameterized, complex model.

9. Dropping movers does not substantially alter the results.

10. Using mvis.ado for Stata allows variables to be distributed as normal, ordinal, logit, or probit, and multinomial. See Royston (2004). 


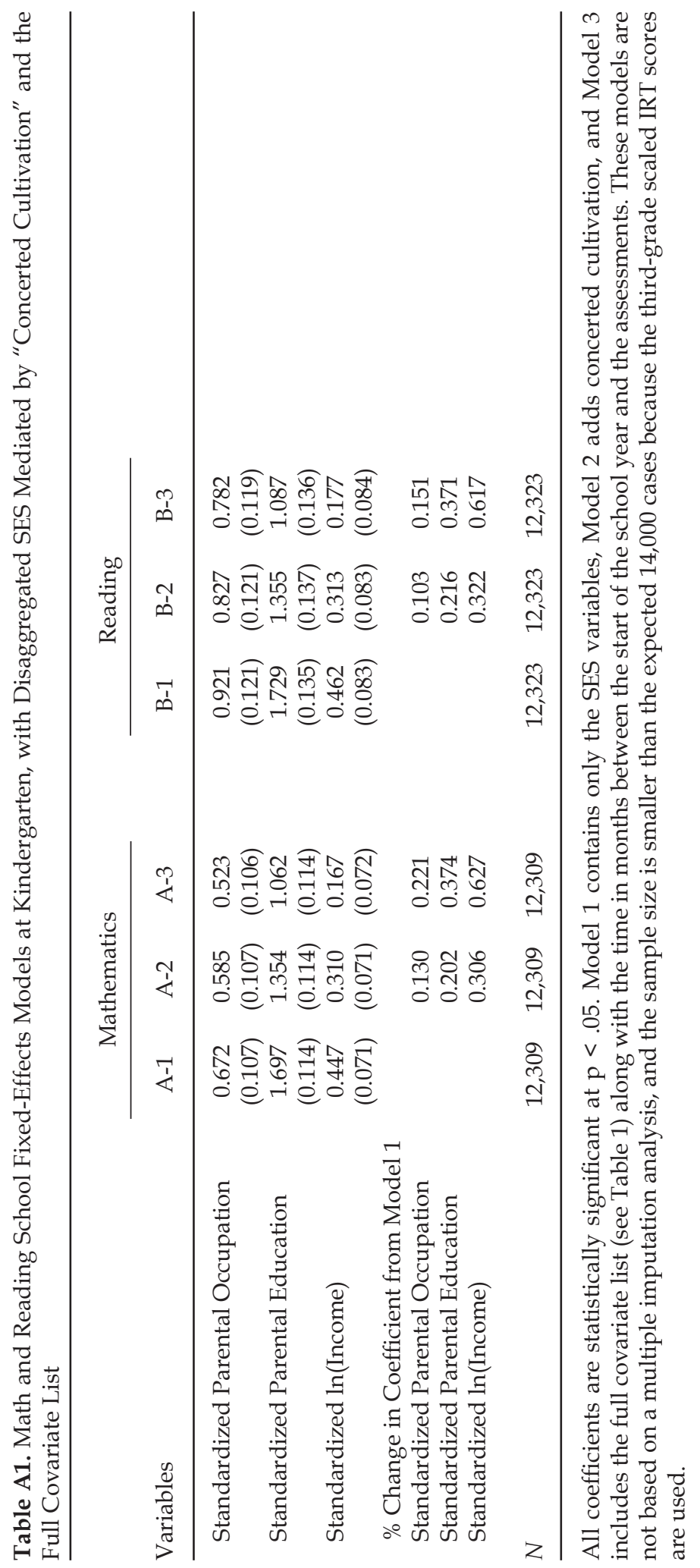




\section{References}

Alexander, Karl L., Doris R. Entwisle, and S. Linda Olson. 2001. "Schools, Achievement, and Inequality: A Seasonal Perspective." Educational Evaluation and Policy Analysis 23:171-91.

Allison, Paul D. 2001. Missing Data. Thousand Oaks, CA: Sage.

Applebee, Arthur N., Judith A. Langer, and Ina V. S. Mullis. 1988. Who Reads Best? Factors Related to Reading Achievement in Grades 3, 7, and 11. Princeton, NJ: Educational Testing Service.

Aschaffenberg, Karen, and Ineke Maas. 1997. "Cultural and Educational Careers: The Dynamics of Social Reproduction." American Sociological Review 62:573-87.

Becker, Gary S. 1964. Human Capital (1st ed.). New York: Columbia University Press.

Boardman, Jason D., Daniel A. Powers, Yolanda C. Padilla, and Robert A. Hummer. 2002. "Lower Birth Weight, Social Factors, and Developmental Outcomes Among Children in the United States." Demography 39:353-68.

Bollen, Kenneth A. 1989. Structural Equations with Latent Variables. New York: John Wiley and Sons.

Bourdieu, Pierre. 1977a. "Cultural Reproduction and Social Reproduction." Pp. 487-511 in Power and Ideology in Education, edited by Jerome Karabel and A. H. Haley. New York: Oxford University Press.

-. 1977b. Outline of the Theory of Practice. New York: Cambridge University Press.

-. 1984. Distinction: A Social Critique of the Judgement of Taste. Cambridge, MA: Harvard University Press.

-. 1986. "The Forms of Capital." Pp. 241-58 in Handbook of Theory and Research for the Sociology of Culture, edited by John Richardson. Westport, CT: Greenwood Press.

Bourdieu, Pierre, and Jean-Claude Passeron. 1977. Reproduction in Education, Society, and Culture. Beverly Hills, CA: Sage.

Bradley, Robert H., and Robert F. Corwyn. 2002. "Socioeconomic Status and Child Development." Annual Review of Psychology 53:371-99.

Bradley, Robert H., Robert F. Corwyn, Harriette Pipes McAdoo, and Cynthia Garcia Coll. 2001. "The Home Environments of Children in the United States, Part I: Variations by Age, Ethnicity, and Poverty Status." Child Development 72:1844-67.

Brooks-Gunn, Jeanne, Pamela K. Klebanov, and Greg J. Duncan. 1996. “Ethnic Differences in Children's In- telligence Test Scores: Role of Economic Deprivation, Home Environment, and Maternal Characteristics." Child Development 67:396-408.

Bryk, Anthony S., and Stephen W. Raudenbush. 1988. "Toward a More Appropriate Conceptualization of Research on School Effects: A Three-Level Hierarchical Linear Model." American Journal of Education 97:65-108.

Burkam, David T., Douglas D. Ready, Valerie E. Lee, and Laura F. LoGerfo. 2004. "Social-Class Differences in Summer Learning Between Kindergarten and First Grade: Model Specification and Estimation." Sociology of Education 77:1-31.

Chall, Jeanne Sternlicht. 1996a. Learning to Read: The Great Debate (3rd ed.). Fort Worth, TX: Harcourt, Brace College Publishers.

-. 1996b. Stages of reading development ( 2 nd ed.). Fort Worth, TX: Harcourt Brace College Publishers.

Chall, Jeanne Sternlicht, Vicki A. Jacobs, and Luke E. Baldwin. 1990. The Reading Crisis: Why Poor Children Fall Behind. Cambridge, MA: Harvard University Press.

Cheadle, Jacob E. 2005. "The Role of 'Concerted Cultivation' in Childhood Academic Achievement Growth Processes: Class and Race Differences from Kindergarten through Third Grade." Unpublished doctoral dissertation, Pennsylvania State University.

Cheadle, Jacob E., and Paul R. Amato. 2007. “'Parental Educational Investments: The 'Concerted Cultivation' Operationalization." Unpublished manuscript, University of Nebraska-Lincoln.

Chin, Tiffani, and Meredith Phillips. 2004. "Social Reproduction and Child-rearing Practices: Social Class, Children's Agency, and the Summer Activity Gap." Sociology of Education 77:185-210.

Coleman, James S. 1988. "Social Capital in the Creation of Human Capital." American Journal of Sociology 94:95-120.

Conley, Dalton. 1999. Being Black, Living in the Red: Race, Wealth, and Social Policy in America. Berkeley: University of California Press.

Cooper, Harris, Barbara Nye, Kelly Charlton, James Lindsay, and Scott Greathouse. 1996. "The Effects of Summer Vacation on Achievement Test Scores: A Narrative and Meta-Analytic Review." Review of Educational Research 66:227-68.

De Boeck, Paul, and Mark Wilson. 2004. Explanatory Item Response Models: A Generalized Linear and Nonlinear Approach. New York: Springer-Verlag. 
DeGarmo, David S., Marion S. Forgatch, and Charles R. Martinez, Jr. 1999. "Parenting of Divorced Mothers as a Link Between Social Status and Boys' Academic Outcomes: Unpacking the Effects of Socioeconomic Status." Child Development 70:1231-45.

De Graaf, Nan Dirk, Paul M.De Graaf, and Gerbert Kraaykamp. 2000. "Parental Cultural Capital and Educational Attainment in the Netherlands: A Refinement of the Cultural Capital Perspective. Sociology of Education 73:92-111.

DiMaggio, Paul. 1982. "Cultural Capital and School Success: The Impact of Status Culture Participation on the Grades of U.S. High School Students." American Sociological Review 47:189-201.

Downey, Douglas. 1995. "When Bigger Is Not Better: Family Size, Parental Resources, and Children's Educational Performance." American Sociological Review 60:746-61.

Downey, Douglas B., Paul T. von Hippel, and Beckett Broh. 2004. "Are Schools the Great Equalizer?" American Sociological Review 65:613-35.

Dumais, Susan A. 2002. "Cultural Capital, Gender, and School Success: The Role of Habitus." Sociology of Education 75:44-68.

Entwisle, Doris R., and Karl L. Alexander. 1989. “Early Schooling as a 'Critical Period' Phenomenon." Pp. 2755 in Research in Sociology of Education and Socialization, edited by K. Namboodiri, and R. G. Corwin. Greenwich, CT: JAI Press.

-. 1992. "Summer Setback: Race, Poverty, School Composition, and mathematics Achievement in the First Two Years of School." American Sociological Review 57:72-84.

-. 1993. "Entry into School: The Beginning School Transition and Educational Stratification in the United States." Annual Review of Sociology 19:401-23.

-. 1994. "Winter Setback: The Racial Composition of Schools and Learning to Read." American Sociological Review 59:446-60.

Entwisle, Doris R., Karl L. Alexander, and Linda Steffel Olson. 1997. Children, Schools, and Inequality. Westport, CT: Westview Press.

Farkas, George. 1996. Human Capital or Cultural Capital? Ethnicity and Poverty Groups in an Urban School District. New York: Aldine de Gruyter.

-. 2003. "Cognitive Skills and Noncognitive Traits and Behaviors in Stratification Processes." Annual Review of Sociology 29.

Farkas, George, and Kurt Beron. 2004. “The Detailed Age
Trajectory of Oral Vocabulary Knowledge: Differences by Class and Race." Social Science Research 33:464-97.

Farkas, George, Daniel Sheenan, Robert P. Grobe, and Yuan Shuan. 1990. "Cultural Resources and School Success: Gender, Ethnicity, and Poverty Groups Within an Urban School District." American Sociological Review 55:127-42.

Fryer, Roland G., Jr., and Steven D. Levitt. 2004. “Understanding the Black-White Test Score Gap in the First Two Years of School." Review of Economics and Statistics 86:447-64.

Guo, Guang. 1998. "The Time of the Influences of Cumulative Poverty on Children's Cognitive Ability and Achievement." Social Forces 71:257-88.

Guo, Guang, and Kathleen Mullan Harris. 2000. “The Mechanisms Mediating the Effects of Poverty on Children's Intellectual Development." Demography 37:431-47.

Guo, Guang, and Elizabeth Stearns. 2002. "The Social Influences on the Realization of Genetic Potential for Intellectual Development." Social Forces 80:881-910. Hanson, Thomas L., Sara McLanahan, and Elizabeth Thomson. 1997. "Economic Resources, Parental Practices, and Children's Well-Being." Pp. 190-238 in Consequences of Growing Up Poor, edited by Greg J. Duncan and Jeanne Brooks-Gunn. New York: Russell Sage Foundation.

Hart, Betty, and Todd R. Risley. 1995. Meaningful Differences in Everyday Experience of Young American Children. Baltimore, MD: Paul H. Brookes.

Heath, Shirley Brice. 1983. Ways with Words. New York: Cambridge University Press.

Honig, Bill. 1996. Teaching Our Children to Read: The Role of Skills in a Comprehensive Reading Program. Thousand Oaks, CA: Corwin Press.

Horvart, Erin M., Elliott B. Weininger, and Annette Lareau. 2003. "From Social Ties to Social Capital: Class Differences in the Relations Between Schools and Parent Networks." American Educational Research Journal 40: 319-51.

Kao, Grace, and Jennifer S. Thompson. 2003. "Racial and Ethnic Stratification in Educational Achievement and Attainment." Annual Review of Sociology 49:417-42.

Kohn, Melvin L. 1977. Class and Conformity: A Study in Values (2nd ed.). Chicago: University of Chicago Press.

Lareau, Annette. 1989. Home Advantage: Social Class and Parental Intervention in Elementary Education. New York: Falmer Press. 
-. 2002. "Invisible Inequality: Social Class and Childrearing in Black Families and White Families." American Sociological Review 67:747-76.

-. 2003. Unequal Childhoods: Class, Race, and Family Life. Berkeley: University of California Press.

Lee, Valerie E., and David T. Burkam. 2002. Inequality at the Starting Gate. Washington, DC: Economic Policy Institute.

Little, Roderick J.A., and Donald B. Rubin. 1987. Statistical Analysis with Missing Data. New York: John Wiley and Sons.

Marsh, Lawrence C., and David R. Cormier. 2002. Spline Regression Models. Thousand Oaks, CA: Sage.

Mayer, Susan. 1997. What Money Can't Buy: Family Income and Children's Life Chances. Cambridge, MA: Harvard University Press.

Muthén, Linda K., and Bengt O. Muthén. 2004. Mplus Users Guide (3rd ed.). Los Angeles: Muthén and Muthén.

National Center for Education Statistics. 2000. ECLS-K Base Year Data Files and Electronic Codebook. Washington, DC: Author.

-. 2002. Early Childhood Longitudinal Study-Kindergarten Class of 1998-99 (ECLS-K), Psychometric Report for Kindergarten Through First Grade. Washington, DC: Author.

-. 2004. User's Manual for the ECLS-K Third Grade Public-Use Data Files and Electronic Code Book. Washington, DC: Author.

Pattillo-McCoy, Mary. (1999). Black Picket Fences: Privilege and Peril Among the Black Middle Class. Chicago: University of Chicago Press.

Phillips, Meredith, Jeanne Brooks-Gunn, Greg J. Duncan, Pamela Klebanov, and Jonathan Crane. 1998. "Family Background, Parenting Practices, and the Black-White Test Score Gap." Pp. 103-48 in The Black-White Test Score Gap, edited by Christopher Jencks and Meredith Phillips. Washington, DC: Brookings Institution Press.

Phillips, Meredith, Mames Crouse, and James Ralph. 1998. "Does the Black-White Test Score Gap Widen After Children Enter School?" Pp. 229-72 in The BlackWhite Test Score Gap, edited by Christopher Jencks and Meredith Phillips. Washington, DC: Brookings Institution Press.

Raudenbush, Stephen W., and Anthony S. Bryk. 2002. Hierarchical Linear Models: Applications and Data Analysis Methods. Thousand Oaks, CA: Sage.

Reardon, Sean F. 2003. "Sources of Educational Inequality: The Growth of Racial/Ethnic and Socioeconomic Test Score Gaps in Kindergarten and First Grade."
Unpublished manuscript, Population Research Institute, Pennsylvania State University, University Park.

Rothstein, Richard. 2004. Class and Schools: Using Social, Economic, and Educational Reform to Close the BlackWhite Achievement Gap. Washington, DC: Economic Policy Institute.

Royston, Patrick. 2004. "Multiple Imputation of Missing Values." Stata Journal 4:227-41.

Sénéchal, Monique, and Jo Anne LeFevre. 2002. "Parental Involvement in the Development of Children's Reading Skill: A Five-Year Longitudinal Study." Child Development 73:445-60.

Shapiro, Thomas M. (2004). The Hidden Cost of Being African American: How Wealth Perpetuates Inequality. New York, Oxford University Press.

Singer, Judith D., and John B. Willett. 2003. Applied Longitudinal Data Analysis: Modeling Change and Event Occurrence. New York: Oxford University Press.

Smith, Judith R., Jeanne Brooks-Gunn, and Pamela Klebanov. 1997. "Consequences of Living in Poverty for Young Children's Cognitive and Verbal Ability and Early School Achievement." Pp. 132-89 in Consequences of Growing Up Poor, edited by Greg J. Duncan, and Jeanne Brooks-Gunn. New York: Russell Sage Foundation.

Smith, Karen E., Susan H. Landry, and Paul R. Swank. 2000. "Does the Content of Mothers' Verbal Stimulation Explain Differences in Children's Development of Verbal and Nonverbal Cognitive Skills?" Journal of School Psychology 38(1):27-49.

Snow, Catherine E., Susan M. Burns, and Peg Griffin. 1998. Preventing Reading Difficulties in Young Children. Washington, DC: National Academy Press.

Stipek, Deborah J., and Rosaleen H. Ryan. 1997. “Economically Disadvantaged Preschoolers: Ready to Learn but Further to Go." Developmental Psychology 33:711-23.

Sui-Chu, Esther Ho, and J. Douglas Willms. 1996. “Effects of Parental Involvement on Eighth-Grade Achievement." Sociology of Education 69:126-41.

Sun, Yongmin. 1998. "The Academic Success of EastAsian-American Students-An Investment Model." Social Science Research 27:432-56.

Teachman, Jay. 1997. "Gender of Siblings, Cognitive Achievement, and Academic Performance: Familial and Nonfamilial Influences on Children." Journal of Marriage and the Family 59:363-74.

-. 2000. "Diversity of Family Structure: Economic and Social Influences." Pp. 32-58 in Handbook of Family Di- 
versity, edited by David H. Demo, Katherine R. Allen, and Mark A. Fine. New York: Oxford University Press.

van der Linden, Wim J., and Ronald K. Hambleton. 1997. “Item Response Theory: Brief History, Common Mod- els, and Extensions." Pp. 1-28 in Handbook of Modern Item Response Theory, edited by Wim J. van der Linden and Ronald K. Hambleton. New York: Spring-Verlag.

Zhou, Min, and Carl L. Bankston III. 1998. Growing Up American. New York: Russell Sage Foundation.

Jacob E. Cheadle, Ph.D., is Assistant Professor of Sociology at the University of Nebraska-Lincoln, prior to which he was a Robert Wood Johnson Health Policy Research Scholar at the University of Michigan. His research interests include childhood health, education, and family processes, along with statistical methodology.

The author is grateful to Bridget Goosby for her helpful comments on this manuscript and Paul Amato, George Farkas, Nancy Landale, Wayne Osgood, Suet-ling Pong, and Sean Reardon for their useful comments and feedback during various stages of the project. This research was partially supported by a grant from the American Educational Research Association, which receives funds for its AERA Grants Program from the National Science Foundation and the National Center for Education Statistics of the Institute of Education Sciences (U.S. Department of Education) under NSF Grant REC-9980573. The opinions expressed here reflect those of the author and do not necessarily reflect those of the granting agencies, and all errors are, of course, the sole responsibility of the author.

Address correspondence to Jacob E. Cheadle, Department of Sociology, University of Nebraska-Lincoln, 737 Oldfather Hall, Lincoln, NE 68588-0324; e-mail: j.e.cheadle@gmail.com 